\title{
Different Oxidation Pathways of 2-Selenouracil and 2-Thiouracil, Natural Components of Transfer RNA
}

\author{
Katarzyna Kulik ${ }^{1,+}+\mathbb{C}$, Klaudia Sadowska ${ }^{2,+}\left(\mathbb{D}\right.$, Ewelina Wielgus ${ }^{1}{ }^{(}$, \\ Barbara Pacholczyk-Sienicka ${ }^{2}$ (D), Elzbieta Sochacka ${ }^{2}$ and Barbara Nawrot 1,*D \\ 1 Centre of Molecular and Macromolecular Studies, Polish Academy of Sciences, Sienkiewicza 112, \\ 90-363 Lodz, Poland; kpieta@cbmm.lodz.pl (K.K.); ms@cbmm.lodz.pl (E.W.) \\ 2 Institute of Organic Chemistry, Lodz University of Technology, Zeromskiego 116, 90-924 Lodz, Poland; \\ klaudia.sadowska@dokt.p.lodz.pl (K.S.); barbara.pacholczyk@p.lodz.pl (B.P.-S.); \\ elzbieta.sochacka@p.lodz.pl (E.S.) \\ * Correspondence: bnawrot@cbmm.lodz.pl; Tel.: +48-42-6803248 \\ + These authors contributed equally to this work.
}

Received: 28 July 2020; Accepted: 13 August 2020; Published: 19 August 2020

\begin{abstract}
Sulfur- and selenium-modified uridines present in the wobble position of transfer RNAs (tRNAs) play an important role in the precise reading of genetic information and tuning of protein biosynthesis in all three domains of life. Both sulfur and selenium chalcogens functionally operate as key elements of biological molecules involved in the protection of cells against oxidative damage. In this work, 2-thiouracil (S2Ura) and 2-selenouracil (Se2Ura) were treated with hydrogen peroxide at 1:0.5, 1:1, and 1:10 molar ratios and at selected $\mathrm{pH}$ values ranging from 5 to 8 . It was found that Se2Ura was more prone to oxidation than its sulfur analog, and if reacted with $\mathrm{H}_{2} \mathrm{O}_{2}$ at a 1:1 or lower molar ratio, it predominantly produced diselenide Ura-Se-Se-Ura, which spontaneously transformed to a previously unknown Se-containing two-ring compound. Its deselenation furnished the major reaction product, a structure not related to any known biological species. Under the same conditions, only a small amount of S2Ura was oxidized to form Ura- $\mathrm{SO}_{2} \mathrm{H}$ and uracil (Ura). In contrast, 10-fold excess hydrogen peroxide converted Se2Ura and S2Ura into corresponding Ura-SeO ${ }_{n} \mathrm{H}$ and $\mathrm{Ura}_{\mathrm{SO}} \mathrm{SO}_{\mathrm{n}} \mathrm{H}$ intermediates, which decomposed with the release of selenium and sulfur oxide(s) to yield Ura as either a predominant or exclusive product, respectively. Our results confirmed significantly different oxidation pathways of 2-selenouracil and 2-thiouracil.
\end{abstract}

Keywords: 2-thiouridine; 2-selenouridine; 2-thiouracil; 2-selenouracil; oxidative stress; modified nucleoside; tRNA

\section{Introduction}

Sulfur and selenium elements are natural components of living organisms in all three domains of life. Among them, the most commonly known are cysteine (Cys) and selenocysteine (Sec) building blocks of proteins and 2-thiouridine (S2U) and 2-selenouridine (Se2U) present in transfer RNAs (tRNAs). Both elements functionally operate as key elements of the enzymes involved in the protection of cells against oxidative damage. These elements are active redox components involved in thiol/disulfide exchange, reactive oxygen species (ROS) metabolism, and redox homeostasis [1-8]. Although selenium and sulfur have similar chemical properties [9], they differ significantly with respect to their polarizability and redox properties [10]. For example, due to weak $\mathrm{Se}-\mathrm{O} \pi$-bonding, Se-oxides are more easily reduced than S-oxides. This so-called "selenium paradox" [11] and other experimental data have allowed the suggestion that selenium-bearing compounds are superior ROS scavengers due to their unique ability to react with oxidizing species in a reversible manner, in contrast to their sulfur analogs [12]. 
Unfortunately, limited data are available in the literature on the susceptibility of S2U/Se2U to oxidation. In the course of our research on the functional properties of chalcogen-containing nucleotides present in transfer RNAs, we have shown that in the presence of hydrogen peroxide at high concentrations or in the presence of oxone ${ }^{\circledR}, 2$-thiouridine (S2U) either as a nucleoside or in an RNA chain undergoes efficient oxidative desulfuration, furnishing uridine (U) and/or 4-pyrimidinone ribonucleoside (H2U) [13,14]. The ratio of products depends on buffer $\mathrm{pH}$, the concentration of reagents, and the electronic properties of a substituent at the C5 position of the nucleobase $[15,16]$. The reaction proceeds through sulfur-oxidized intermediates (bearing a sulfenic, sulfinic, or sulfonic moiety) and is catalyzed in vitro by cytochrome C [17]. The S2U-RNA $\rightarrow$ H2U-RNA transformation leads to the loss of U-A base pairing in RNA duplexes [14]. Although this kind of tRNA damage has not been confirmed in cells and is still a subject of research, one can consider that it may impair tRNA function during protein synthesis due to the disruption of codon-anticodon interactions.

Recently, Hondal's group investigated the oxidative transformation of 2-thio-and 2-selenouracils substituted at position 5 with a nonnative substituent (introduced to enhance nucleobase solubility in aqueous media), which is a carboxyl group directly attached to C5 (c5S2Ura and c5Se2Ura), and demonstrated that 5-carboxy-2-thiouracil in the presence of a 1:1 molar ratio of $\mathrm{H}_{2} \mathrm{O}_{2}$ underwent irreversible desulfuration, leading to 5-carboxyuracil. In contrast, the 2-seleno-analog, under the same conditions, was converted into the corresponding diselenide and seleninic acid, which, in a reducing environment, could be converted back to the starting 5-carboxy-2-selenouracil [18]. This result allowed them to conclude that selenium-containing biomolecules are resistant to permanent oxidation, and this is the main reason for naturally occurring selenium in both 2-selenouridine- and Sec-containing proteins. This conclusion complementary to the latest data on the role of seleno modifications in tRNA ensuring the fidelity of the reading of synonymous $3^{\prime}-G$ ending codons [19], prompted us to perform more detailed studies on the oxidation of 2-thiouracil (S2Ura) and 2-selenouracil (Se2Ura), especially in light of the recently discovered "oxidative desulfuration" of S2U, leading predominantly to 4-pyrimidinone derivatives [13-17].

In work presented here, we treated 2-selenouracil (Se2Ura, 1a) and 2-thiouracil (S2Ura, 1b) with hydrogen peroxide under different conditions (at different concentrations and various $\mathrm{pH}$ values) and identified intermediates and final products at several time points using ${ }^{1} \mathrm{H}$ NMR spectroscopy and ultra-performance liquid chromatography coupled with high-resolution mass spectrometry and photodiode array detection (UPLC-PDA-ESI(-)-HRMS). The obtained data allowed us to propose possible transformation paths for selenium- and sulfur-containing uracils and to characterize their redox properties.

\section{Results}

2.1. General Approach for Analysis of the Course of Oxidation of 2-Selenouracil (1a) and 2-Thiouracil (1) and Identification of the Reaction Products

To obtain data on a sequence of events during oxidation of 2-selenouracil (1a, Se2Ura) and 2-thiouracil (1b, S2Ura), $10 \mathrm{mM}$ solutions in phosphate buffer at $\mathrm{pH}$ 5.0, 7.4, or 8.0 or in water were reacted at room temperature (r.t.) with 5,10 , or $100 \mathrm{mM}$ hydrogen peroxide (1:0.5, 1:1, and 1:10 molar ratio, respectively). The reaction progress (from $1 \mathrm{~min}$ to $24 \mathrm{~h}$ ) and structural data on the intermediates/products were gathered from ${ }^{1} \mathrm{H}$ NMR and UPLC-PDA-ESI(-)-HRMS measurements. The relative content of the detected compounds was calculated using integrations of ${ }^{1} \mathrm{H}$ NMR signals for non-exchangeable $\mathrm{H} 5$ and $\mathrm{H} 6$ protons ( $\delta$ range 8.8-5.2 ppm). The UPLC-ESI(-)-MS retention times (Rt, $\mathrm{min}$ ), $\mathrm{m} / \mathrm{z}$ values of the ions, which correspond to the deprotonated molecules, $\lambda_{\max }$ in UV/VIS spectra $(\mathrm{nm})$, and ${ }^{1} \mathrm{H}$ NMR chemical shifts $(\delta, \mathrm{ppm})$ for $\mathrm{H} 5$ and $\mathrm{H} 6$ protons and coupling constants $J_{H 6-H 5}$ for all identified compounds are presented in Table 1. Spectral data for all identified compounds are given in the Supplementary Materials (Figures S1-S20). 
Table 1. UPLC-PDA-ESI (-)-HRMS and ${ }^{1} \mathrm{H}$ NMR data of $\mathbf{1 a}$ and $\mathbf{1 b}$ and their oxidation products $\mathbf{2}-\mathbf{1 0}$. The UPLC retention time (Rt, $\mathrm{min}$ ) and $\mathrm{m} / \mathrm{z}$ data (atomic mass unit to its formal charge ratio) for $[\mathrm{M}-\mathrm{H}]^{-}$ in negative mode, the maximum wavelength $\lambda_{\max }$ in UV/VIS spectra (nm), and ${ }^{1} \mathrm{H}$ NMR chemical shifts $(\delta, \mathrm{ppm})$ of $\mathrm{H} 5$ and $\mathrm{H} 6$ protons and their coupling constant $J_{\mathrm{H} 6-\mathrm{H} 5}$ for all identified compounds are given.

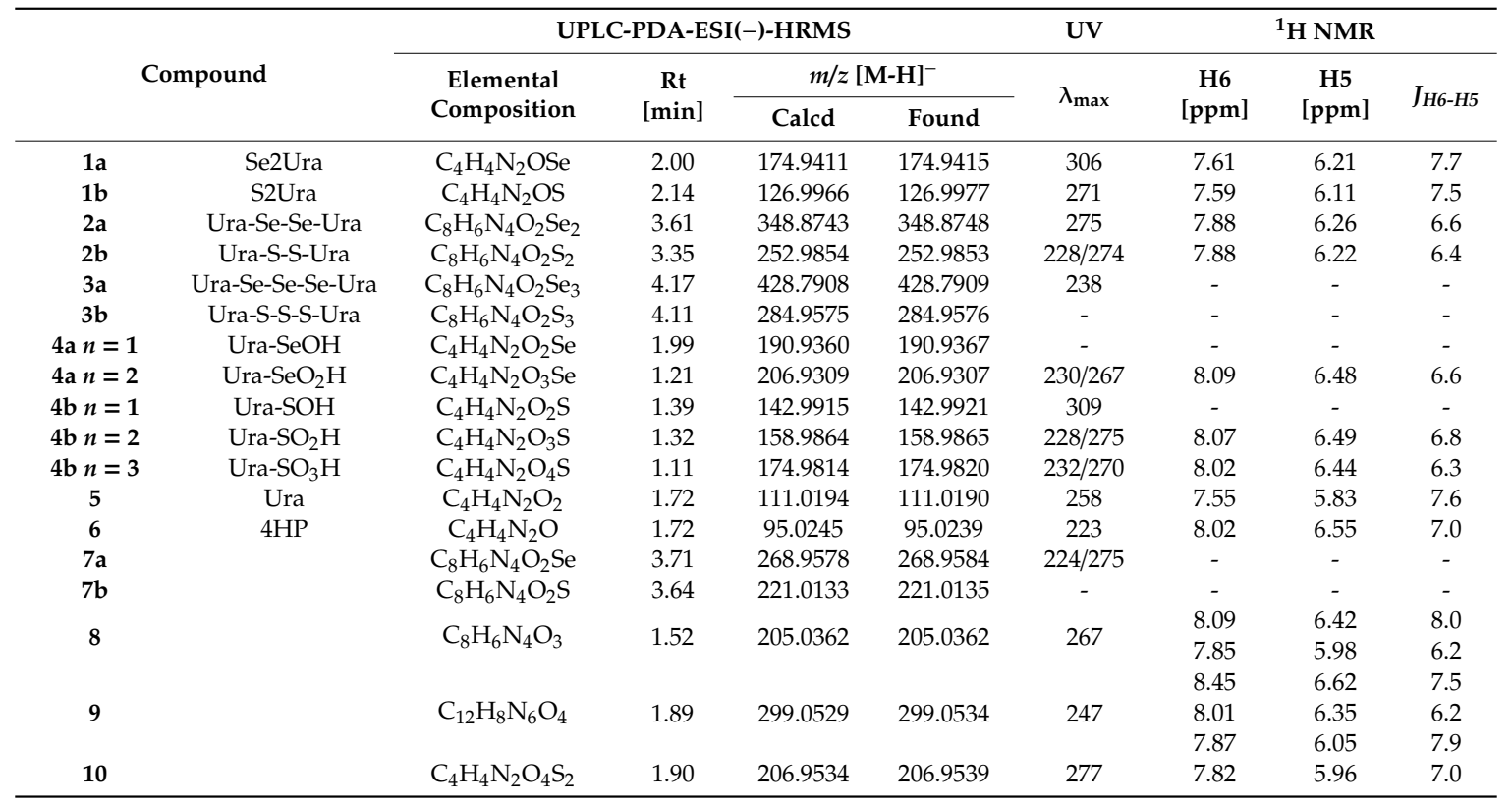

\subsection{Analysis of the Oxidation Course of Se2Ura (1a)}

\subsubsection{The Reaction of Se2Ura and $\mathrm{H}_{2} \mathrm{O}_{2}$ at a 1:1 Molar Ratio, pH 7.4}

Preliminary experiments showed that to obtain reliable data on possibly all intermediates, the oxidation process should be performed at a $\mathrm{pH}$ close to neutral, so $\mathrm{pH} 7.4$ was selected. A set of ${ }^{1} \mathrm{H}$ NMR spectra (Figure 1) was acquired in the 24-h time course and compared with the spectrum of substrate 1a. At similar time points, the UPLC-PDA-ESI(-)-HRMS data (Figure 2a) were collected. Dynamic changes were observed in the first stage of the reaction course $(t<60$ min, see Figure $2 b)$, since over the first 1-2 min, the resonances and MS signals characteristic of $1 \mathrm{a}(\delta 7.61 \mathrm{ppm}$ and $6.21 \mathrm{ppm}$; $m / z$ 174.9415) disappeared almost completely, while a new compound appeared, which was identified as diselenide 2a (Ura-Se-Se-Ura) ( $\delta 7.88$ ppm and 6.26 ppm; $m / z$ 348.8748) (Scheme 1). Later (from 5 to $30 \mathrm{~min}$ ), the diselenide content gradually decreased, and after ca. $2 \mathrm{~h}, \mathbf{2 a}$ disappeared almost completely (see Figure 2a,b). Simultaneously, a new, stable product gradually appeared, for which two pairs of resonance signals were observed, i.e., $\delta 8.09$ and 7.85 ppm for two different H6 protons and $\delta$ 6.42 and 5.98 ppm for two H5 protons. The $m / z 205.0362$ value in the mass spectrum for this product was lower than that for diselenide $\mathbf{2 a}(\mathrm{m} / \mathrm{z}$ 348.8748) but higher than that for 1a $(\mathrm{m} / \mathrm{z}$ 174.9415). Detailed analysis (UPLC-ESI(-)-MS/MS fragmentation, Figure 3c) revealed that a selenium-free, two-ring compound 8 (Scheme 1) was formed, which, after $24 \mathrm{~h}$, constituted $87 \%$ of the reaction products. The traces of compound 7a $(\mathrm{m} / \mathrm{z} 268.9584$, Figure 3a), which might be a selenium-bearing precursor of 8, were observed in the UPLC-HRMS measurement $(\Delta m / z 63.9222$ between the ions related to the deprotonated molecules of $7 \mathbf{a}$ and 8 conformed to the Se $\rightarrow$ O replacement) but not in the ${ }^{1} \mathrm{H}$ NMR spectrum. The $\mathrm{N} 1_{\mathrm{a}}-\mathrm{C} 2_{\mathrm{b}}$ covalent bonding between two rings was confirmed by the presence of fragmentation ions at $m / z 163.0305$ and 134.0355 for 8 and at $m / z 225.9521$ and 162.0300 for $7 \mathrm{a}$ in the collision-induced dissociation (CID) spectra. The pH-dependent UV measurements of 8 in the $\mathrm{pH}$ range of 3-10 are shown in Figure 2c. 


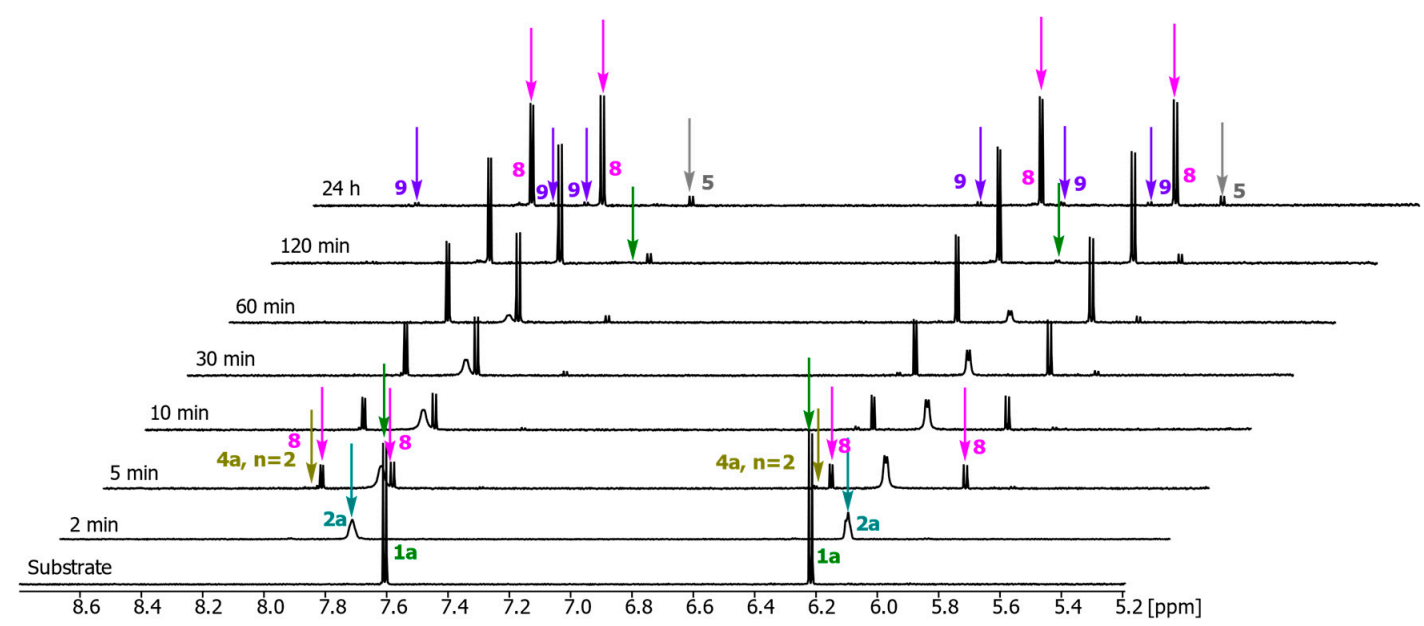

Figure 1. ${ }^{1} \mathrm{H}$ NMR analysis of the reaction mixtures for the oxidation of Se2Ura $(\mathbf{1 a}, 10 \mathrm{mM})$ with $\mathrm{H}_{2} \mathrm{O}_{2}$ $(10 \mathrm{mM})$ in $67 \mathrm{mM}$ phosphate buffer at $\mathrm{pH} 7.4$ and room temperature.

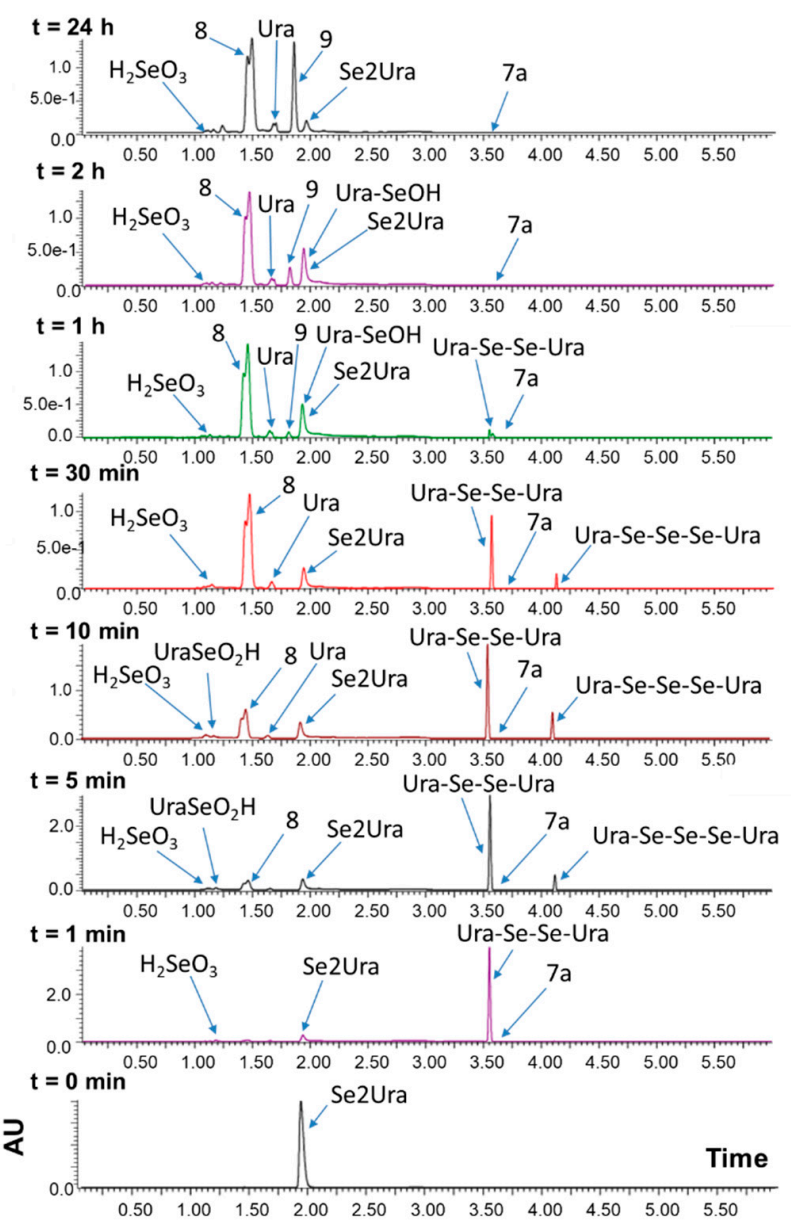

(a)

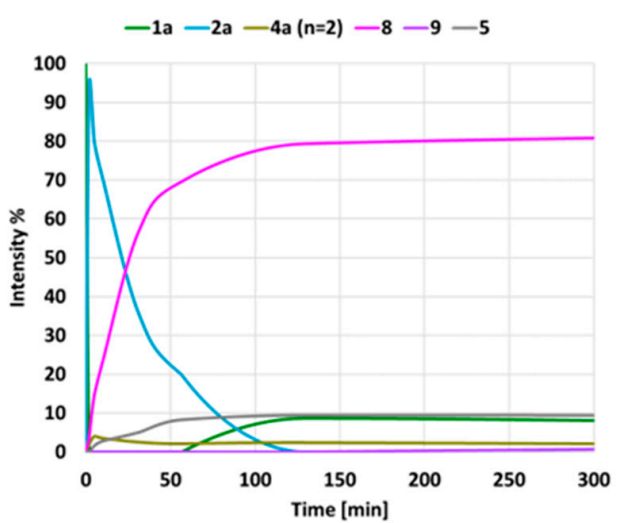

(b)

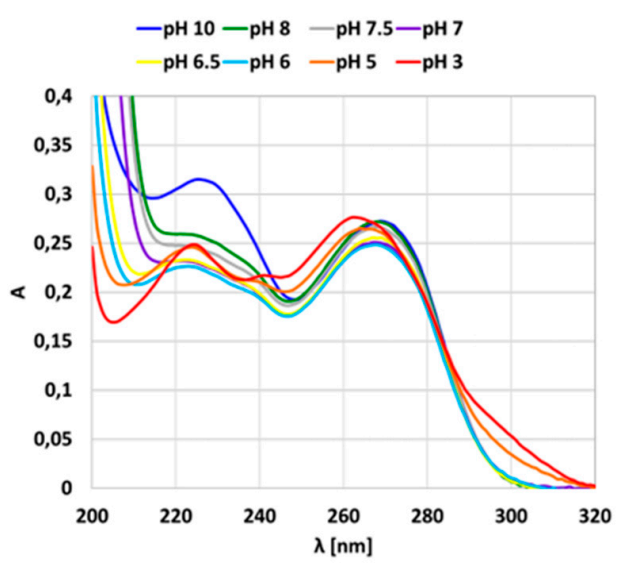

(c)

Figure 2. (a) UPLC-PDA chromatographic analysis and (b) time course of the formation of products for the oxidation reaction of Se2Ura $(\mathbf{1 a}, 10 \mathrm{mM})$ with $\mathrm{H}_{2} \mathrm{O}_{2}(10 \mathrm{mM})$ in $67 \mathrm{mM}$ phosphate buffer at $\mathrm{pH} 7.4$ and r.t. The $\mathrm{m} / \mathrm{z}$ values are given in Table 1. The time course of the formation/disappearance of each product was assessed by ${ }^{1} \mathrm{H}$ NMR integration data. (c) The $\mathrm{pH}$-dependent UV spectra of 8 in the $\mathrm{pH}$ range from 3 to 10 . The inorganic selenous acid was identified by UPLC-ESI(-)-HRMS, and its retention time was determined based on extracted ion chromatograms (EICs) for the ion corresponding to its deprotonated molecule $(\mathrm{m} / \mathrm{z}$ 128.909). 


\begin{tabular}{l}
$\mathbf{1 a}$ \\
\hline $\mathrm{pH} 8.0$ \\
$\mathrm{pH} 5.0$
\end{tabular}

Minor products:<smiles></smiles>

Scheme 1. Oxidation products formed in the reaction of $\mathbf{1 a}$ (2-selenouracil, $10 \mathrm{mM}$ ) with $\mathrm{H}_{2} \mathrm{O}_{2}(10 \mathrm{mM})$ in phosphate buffer at $\mathrm{pH}$ 7.4. The contents of products found after $24 \mathrm{~h}$ at other $\mathrm{pH}$ values are given below the structures. The minor products were identified in the reaction mixture time course but were not present after $24 \mathrm{~h}$.

The structure of 8 was confirmed by NMR analysis in the 2D HMBC (Heteronuclear Multiple Bond Coherence) spectrum, where the correlation between the $\mathrm{H} 6_{\mathrm{a}}$ proton $(\delta 7.85 \mathrm{ppm})$ and the $\mathrm{C} 2_{\mathrm{b}}$ carbon ( $\delta 156.10 \mathrm{ppm}$ ) indicated a covalent bond between $\mathrm{N}_{\mathrm{a}}$ and $\mathrm{C} 2_{\mathrm{b}}$. Moreover, the same carbon atom $\mathrm{C}_{\mathrm{b}}$ also had a three-bond correlation with proton $\mathrm{H} 6_{\mathrm{b}}$ at $8.10 \mathrm{ppm}$ (see Figure $4 \mathrm{a}$ ). The ${ }^{1} \mathrm{H}$ and ${ }^{13} \mathrm{C}$ NMR spectra recorded for 8 are shown in Figures S9 and S10.

Another minor product (ca. 5\%), identified in the reaction mixture after $24 \mathrm{~h}$, was found to be three-ring derivative 9 (see Scheme 1). Its structure was confirmed by UPLC-HRMS analysis $(\mathrm{m} / \mathrm{z} 299.0534)$ and ${ }^{1} \mathrm{H}$ NMR resonances for three different $\mathrm{H} 5$ atoms and three different $\mathrm{H} 6$ atoms (Figures 1 and 2a, Table 1). The UV spectra over a broad $\mathrm{pH}$ range (see Figure S13) were almost identical, and only one band with $\lambda_{\max } 257 \mathrm{~nm}$ at $\mathrm{pH} 3$ shifted to $245 \mathrm{~nm}$ at $\mathrm{pH} 10$. The collision-induced dissociation (CID) spectrum of 9 (Figure 3d) confirmed the presence of the three six-membered rings a, $\mathrm{b}$, and $\mathrm{c}$ connected by $\mathrm{N} 1_{\mathrm{a}}-\mathrm{C} 2_{\mathrm{b}}$ and $\mathrm{N} 1_{\mathrm{b}}-\mathrm{C} 2_{\mathrm{c}}$ covalent bonds. The structure was also confirmed by the $2 \mathrm{D}$ HMBC spectrum shown in Figure $4 \mathrm{~b}$, where three bond correlations between $\mathrm{C}_{\mathrm{a}}$ and $\mathrm{H} 6_{\mathrm{a}}$ $(\delta 7.90 \mathrm{ppm})$ and $\mathrm{H} 6_{\mathrm{b}}(\delta 8.46 \mathrm{ppm})$ were found. Similarly, correlations between $\mathrm{C} 2_{\mathrm{c}}(\delta 156.79 \mathrm{ppm})$ and $\mathrm{H}_{\mathrm{b}}(\delta 8.46 \mathrm{ppm})$ and $\mathrm{H} 6_{\mathrm{c}}(\delta 8.02 \mathrm{ppm})$ were identified.

Our approach also allowed the identification of triselenide 3a (Ura-Se-Se-Se-Ura, $m / z$ 428.7909) with its highest abundance (ca. 5\%) after $10 \mathrm{~min}$ and final disappearance after $2 \mathrm{~h}$. Very weak signals for 1a were noted after ca. $60 \mathrm{~min}$ (Figure 2a), indicating its partial restoration; however, its content after $24 \mathrm{~h}$ was virtually negligible. At an early time point $(5 \mathrm{~min})$, small amounts of seleninic acid $4 \mathbf{a}(n=2$, Ura-SeO ${ }_{2} \mathrm{H}, \mathrm{m} / z$ 206.9307) appeared, for which resonances at $\delta 8.09 \mathrm{ppm}$ and $\delta 6.48 \mathrm{ppm}$ were noted. A minute amount of very reactive selenenic acid, Ura-SeOH $(4 \mathbf{a}, n=1, m / z$ 190.9367), was observed at a rather late stage of ca. $60 \mathrm{~min}$, so its appearance might be attributed to the disproportionation of an intermediate compound(s). After $24 \mathrm{~h}, 8 \%$ uracil (5) was identified, and the residual amount of inorganic $\mathrm{H}_{2} \mathrm{SeO}_{3}$ was observed in UPLC-HRMS analysis. 


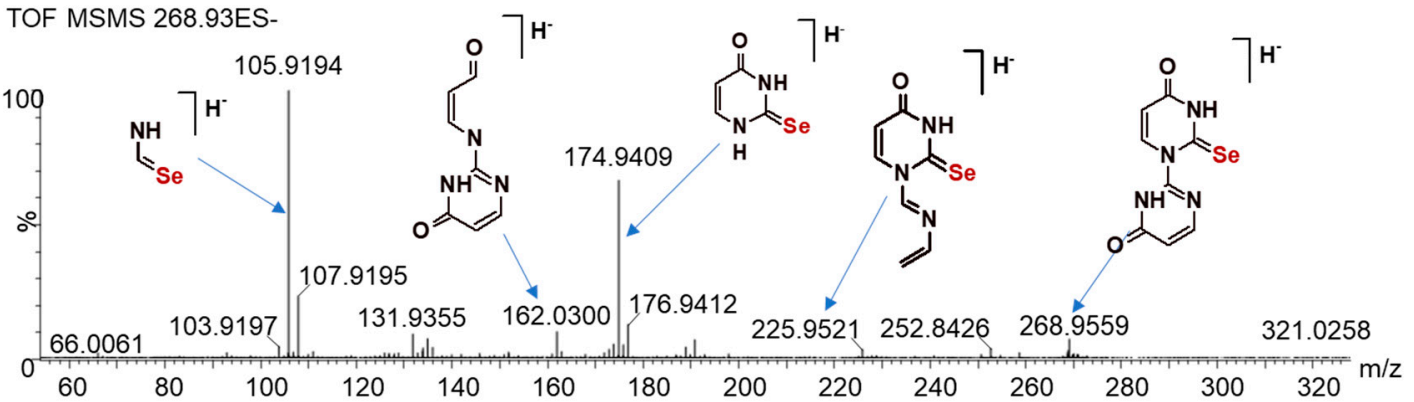

(a)

TOF MSMS 221.01ES-

100

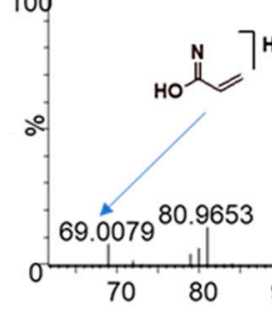
(1)

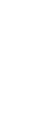

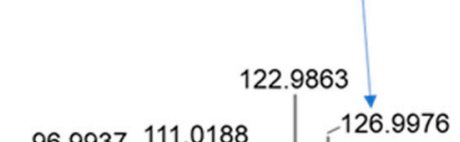

$90 \quad 100 \quad 110 \quad 120$
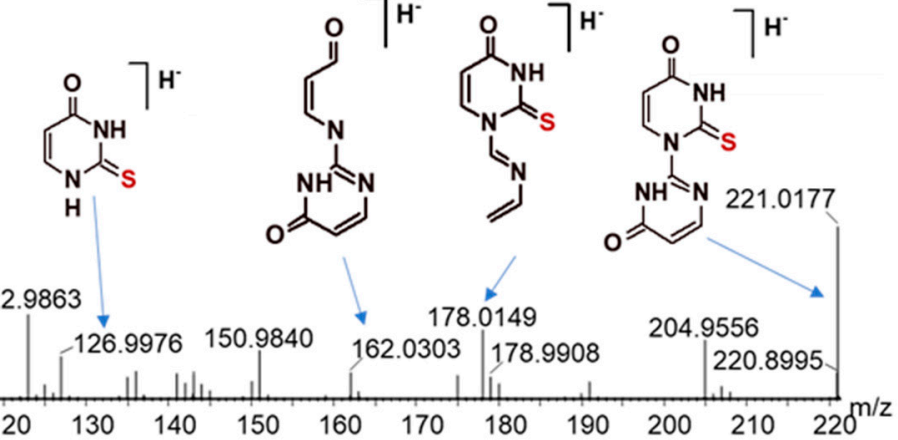

(b)

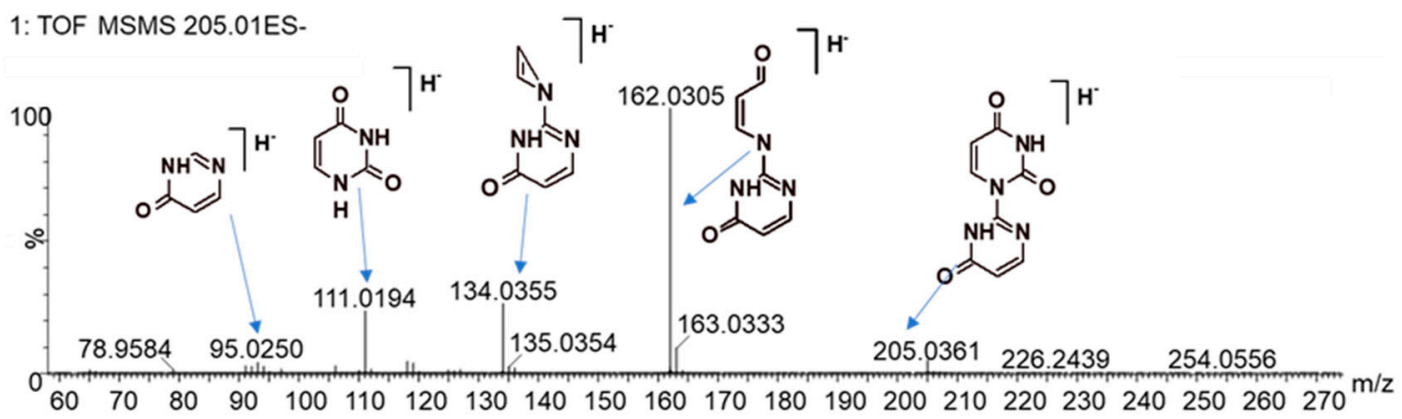

(c)

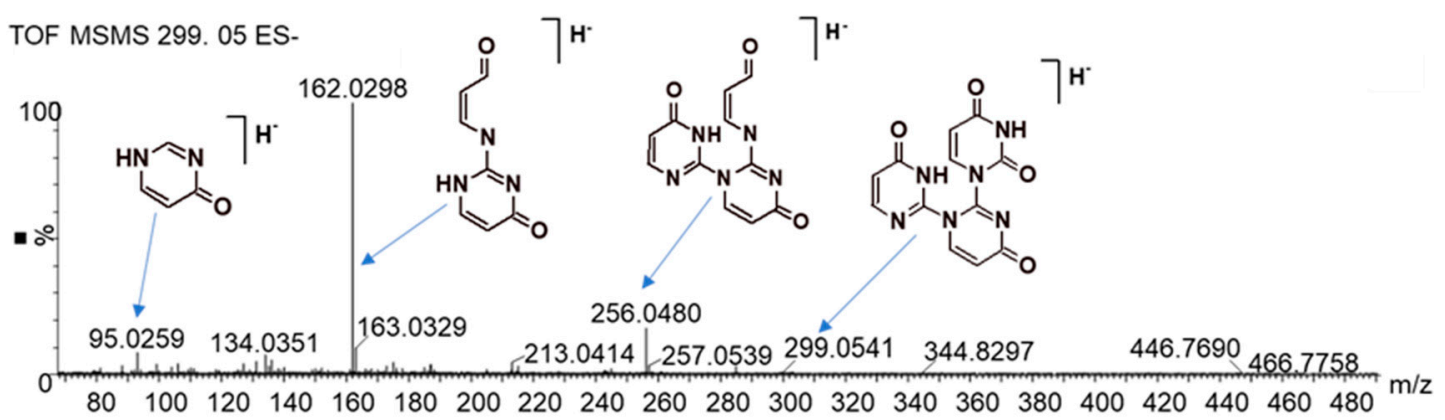

(d)

Figure 3. UPLC/ESI(-)-MS/MS mass spectra of the deprotonated molecule of $7 \mathbf{a}(\mathbf{a}), \mathbf{7 b}(\mathbf{b}), \mathbf{8}(\mathbf{c})$, and $\mathbf{9}$ (d) recorded with collision energy ramping from 15 to $35 \mathrm{eV}$. 


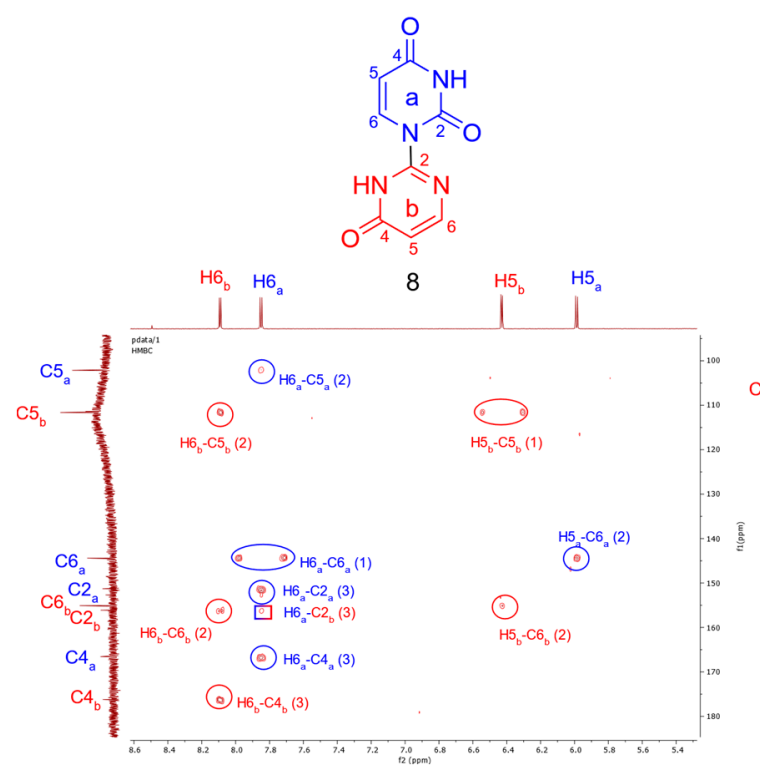

(a)

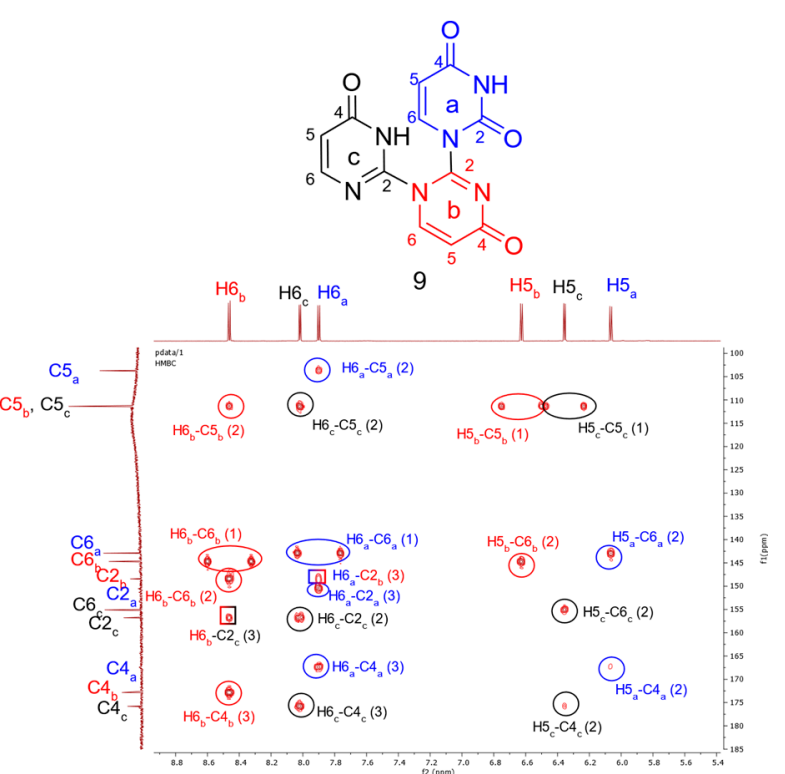

(b)

Figure 4. The ${ }^{1} \mathrm{H} /{ }^{13} \mathrm{C}$-HMBC spectra (in $\mathrm{D}_{2} \mathrm{O}$ ) showing the correlations between the hydrogen atoms and the carbon atoms in 8 (a) and 9 (b).

In an analogous reaction carried out in phosphate buffer at $\mathrm{pH}$ 8.0, the stability of diselenide 2a decreased remarkably since after $1 \mathrm{~min}$, the efficient formation of $\mathbf{8}$ was observed (see NMR analysis Figure S21). Compared to that detected for the reaction at pH 7.4, more seleninic acid $4 \mathbf{a}(n=2)$ was detected in the reaction mixture after $24 \mathrm{~h}$. The formation of the three-ring product 9 was also observed. After $24 \mathrm{~h}$, the reaction mixture consisted of compounds $8(48 \%), 9(17 \%), 5(6 \%), \mathbf{4 a}(n=2)(15 \%)$, and reconstituted 1a (14\%) (Scheme 1).

Finally, the reactions were performed under slightly acidic conditions (in phosphate buffer at $\mathrm{pH} 5.0$ and in deionized water at $\mathrm{pH}$ 6.5). The relevant ${ }^{1} \mathrm{H}$ NMR spectra (Figure S22) indicated that after $2 \mathrm{~min}$ at $\mathrm{pH} 5.0$, diselenide $2 \mathrm{a}$ was not detected, and the two-ring products 8 (46\%) and uracil (5) $(54 \%)$ were highly abundant. Interestingly, neither three-ring compound 9 nor restored 1a were found. For the reaction carried out in the water, the reaction course was quite similar, and $\mathbf{8}$ and $\mathbf{5}$ were obtained in 37\% and 63\% yield, respectively (Figure S23). This change in the product ratio was not unexpected since the reacting mixture became more acidic (to $\mathrm{pH} 1.0-2.5$ ) as inorganic $\mathrm{H}_{2} \mathrm{SeO}_{3}$ was released.

\subsubsection{The Reaction of Se2Ura and $\mathrm{H}_{2} \mathrm{O}_{2}$ at a 1:0.5 Molar Ratio and $\mathrm{pH} 7.4$}

The reaction of $1 \mathrm{a}(10 \mathrm{mM})$ was carried out with 0.5 equivalents $(5 \mathrm{mM})$ of $\mathrm{H}_{2} \mathrm{O}_{2}$ in phosphate buffer at pH 7.4 and monitored by ${ }^{1} \mathrm{H}$ NMR (see Figure 5 and Figure S24). Interestingly, in this case 1a was almost immediately converted to diselenide $\mathbf{2 a}$ as a sole product (see Figure 5), and only a small amount of $4 \mathbf{a}\left(n=2, \mathrm{Ura}-\mathrm{SeO}_{2} \mathrm{H}\right)$ was observed after longer reaction times. Over the next $60 \mathrm{~min}$, the formation of the two-ring and three-ring derivatives $\mathbf{8}$ and $\mathbf{9}$ was observed. After $24 \mathrm{~h}$, the integration of ${ }^{1} \mathrm{H}$ NMR signals indicated the formation of $8(57 \%), 9(26 \%)$, and $5(6 \%)$, as well as restored $1 \mathrm{a}(11 \%)$ (Scheme 2). 


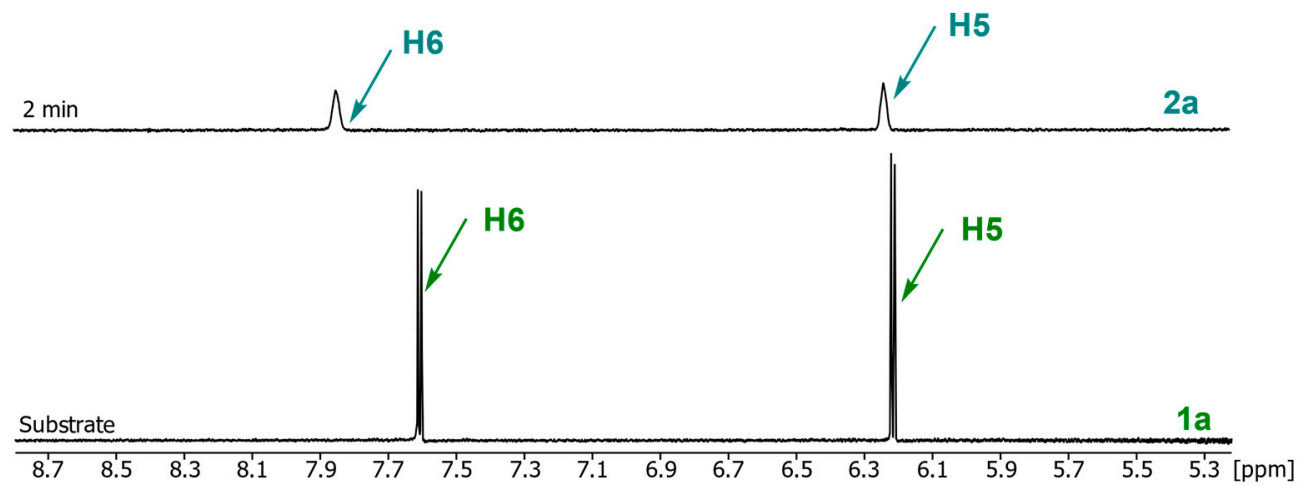

Figure 5. ${ }^{1} \mathrm{H}$ NMR analysis (H5 and H6 signals) of the reaction mixtures for the oxidation of Se2Ura (1a, $10 \mathrm{mM}$ ) with $\mathrm{H}_{2} \mathrm{O}_{2}(5 \mathrm{mM})$ in $67 \mathrm{mM}$ phosphate buffer at $\mathrm{pH} 7.4$, r.t, taken after 2 min (upper spectrum) and with reference 1a, lower spectrum. The figure presents the complete transformation of Se2Ura to Ura-Se-Se-Ura with 0.5 eq. of hydrogen peroxide, through two consecutive reactions: Se2Ura $\rightarrow$ Ura-SeOH and Se2Ura + Ura-SeOH $\rightarrow$ Ura-Se-Se-Ura.<smiles>O=c1cc[nH]c(=O)[nH]1</smiles>

$$
\frac{5 \mathrm{mM} \mathrm{H}_{2} \mathrm{O}_{2}}{\underset{\text { phosphate buffer pH } 7.4}{\text { r.t., } 24 \mathrm{~h}}}
$$

$1 a$<smiles>COc1ccc(CC(C)C)nc1-c1ncco1</smiles>

$2 a$<smiles></smiles>

$8(57 \%)$<smiles></smiles>

9 (26\%)

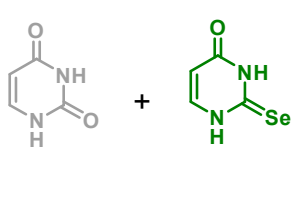

$5(6 \%)$

1a (11\%)

Scheme 2. Oxidation products formed in the reaction of 2-selenouracil $(10 \mathrm{mM})$ with $\mathrm{H}_{2} \mathrm{O}_{2}(5 \mathrm{mM})$ in phosphate buffer at $\mathrm{pH} 7.4$.

2.2.3. The Reaction of Se2Ura and $\mathrm{H}_{2} \mathrm{O}_{2}$ at a 1:10 Molar Ratio and pH 7.4

A 10-fold molar excess of $\mathrm{H}_{2} \mathrm{O}_{2}$ towards Se2Ura (1a) caused almost immediate disappearance of $1 \mathbf{a}$ (Figures S25 and S26) and formation of the seleninic acid derivative $4 \mathbf{a}\left(n=2, \mathrm{Ura}^{-\mathrm{SeO}} \mathrm{H}_{2} \mathrm{H}\right)$ and diselenide $2 \mathrm{a}$ in yields of ca. $16 \%$ and $75 \%$, respectively. The ${ }^{1} \mathrm{H}$ NMR spectrum recorded after $5 \mathrm{~min}$ indicated an increased amount of $4 \mathbf{a}(n=2)$ at the expense of diselenide $2 \mathbf{a}$. After $24 \mathrm{~h}$, the mixture consisted of uracil $\left(5,89 \%\right.$, from the decomposition of $\left.\mathrm{Ura}-\mathrm{SeO}_{2} \mathrm{H}\right)$ and the two-ring derivative 8 $(11 \%$, from the rearrangement of diselenide $2 \mathbf{a})$ (Scheme 3). Interestingly, no three-ring product was detected. Only traces of $7 \mathbf{a}$, as well as inorganic $\mathrm{H}_{2} \mathrm{SeO}_{3}$ and $\mathrm{H}_{2} \mathrm{SeO}_{4}$, were detected by UPLC-HRMS (Figure S26).<smiles>O=c1cc[nH]c(=O)[nH]1</smiles>

$1 \mathrm{a}$

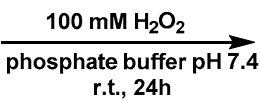
r.t., 24h buffer at $\mathrm{pH}$ 7.4.

\subsection{Analysis of the Oxidation Course of S2Ura (1b)}

2.3.1. The Reaction of $\mathrm{S} 2 \mathrm{Ura}$ and $\mathrm{H}_{2} \mathrm{O}_{2}$ at a 1:1 Molar Ratio and $\mathrm{pH}$ 7.4.

The reaction of S2Ura $(\mathbf{1 b}, 10 \mathrm{mM})$ with hydrogen peroxide at a 1:1 molar ratio (Scheme 4, Figures 6 and 7a) was much slower than that of the selenium analog 1a, and after $24 \mathrm{~h}$, ca. $45 \%$ of the substrate remained unchanged. Formation of sulfinic acid $4 \mathbf{b}\left(n=2, \mathrm{Ura}-\mathrm{SO}_{2} \mathrm{H}\right)(\delta 8.07$ and $6.49 \mathrm{ppm}$, 
$\mathrm{m} / \mathrm{z} 158.9865)$ was noted immediately after mixing the reactants. Its maximum concentration occurred after approximately $2 \mathrm{~h}$ and decreased to approximately $34 \%$ after $24 \mathrm{~h}$. In contrast to the oxidation of $\mathbf{1 a}$, where at the early time points, diselenide $\mathbf{2} \mathbf{a}$ was the main intermediate, disulfide $\mathbf{2} \mathbf{b}(\delta 7.88$ and $6.22 \mathrm{ppm}, \mathrm{m} / \mathrm{z} 252.9853)$ was present in a small amount only $(0.4 \%)$, and it was stable until the end of the experiment. At consecutive time points, other low-abundance compounds were identified: sulfonic acid $4 \mathbf{b}\left(n=3, \mathrm{Ura}-\mathrm{SO}_{3} \mathrm{H}, \delta 8.02\right.$ and $6.44 \mathrm{ppm}, \mathrm{m} / z$ 174.9820, approx. $\left.5 \%\right)$, sulfenic acid $4 \mathbf{b}$ ( $n=1$, Ura-SOH, $m / z$ 142.9921), 4-pyrimidinone $(6, \delta 8.02$ and $6.55 \mathrm{ppm}, \mathrm{m} / z$ 95.0239), trisulfide $3 \mathbf{b}$ $(\mathrm{m} / \mathrm{z} 284.9576)$, and the 2-thiouracil member of the Bunte salt family $10(\delta 7.82$ and 5.96, $\mathrm{m} / \mathrm{z} 206.9539$, see Figure S27), as well as the two-ring derivatives $7 \mathbf{b}(\mathrm{m} / \mathrm{z} 221.0135$, see Figure $3 \mathbf{b})$ and $\mathbf{8}(\mathrm{m} / \mathrm{z} 205.0362)$. After $24 \mathrm{~h}$, the reaction mixture contained three major products (Scheme 4): substrate $\mathbf{1 b}(37 \%)$, sulfinic acid $4 \mathbf{b}(n=2,34 \%)$, and uracil $(5,17 \%)$. The spectroscopic and chromatographic data for the identified compounds are given in Table 1 , and ${ }^{1} \mathrm{H}$ NMR spectra, as well as the time course of the oxidation reaction (Figure S28), are included in the Supplementary Materials.

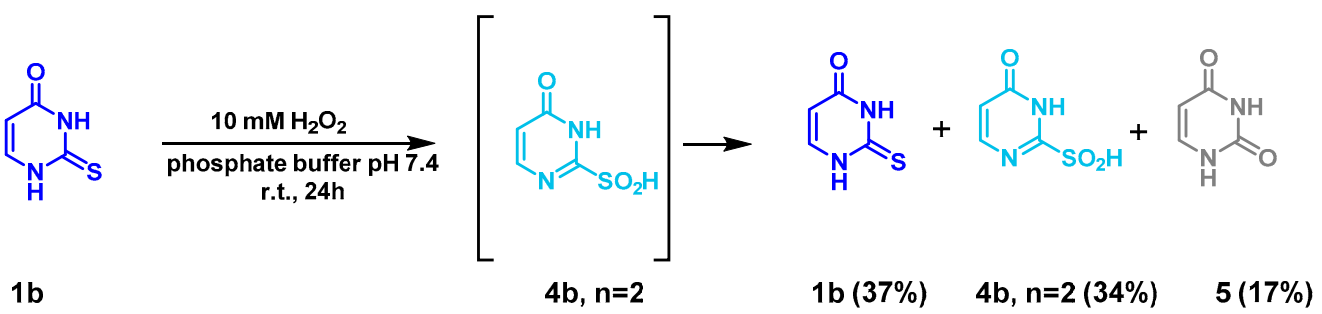

Minor products:<smiles></smiles>

Scheme 4. The identified products of a reaction of 2-thiouracil $(10 \mathrm{mM})$ with $\mathrm{H}_{2} \mathrm{O}_{2}(10 \mathrm{mM})$ in phosphate buffer at $\mathrm{pH} 7.4$.

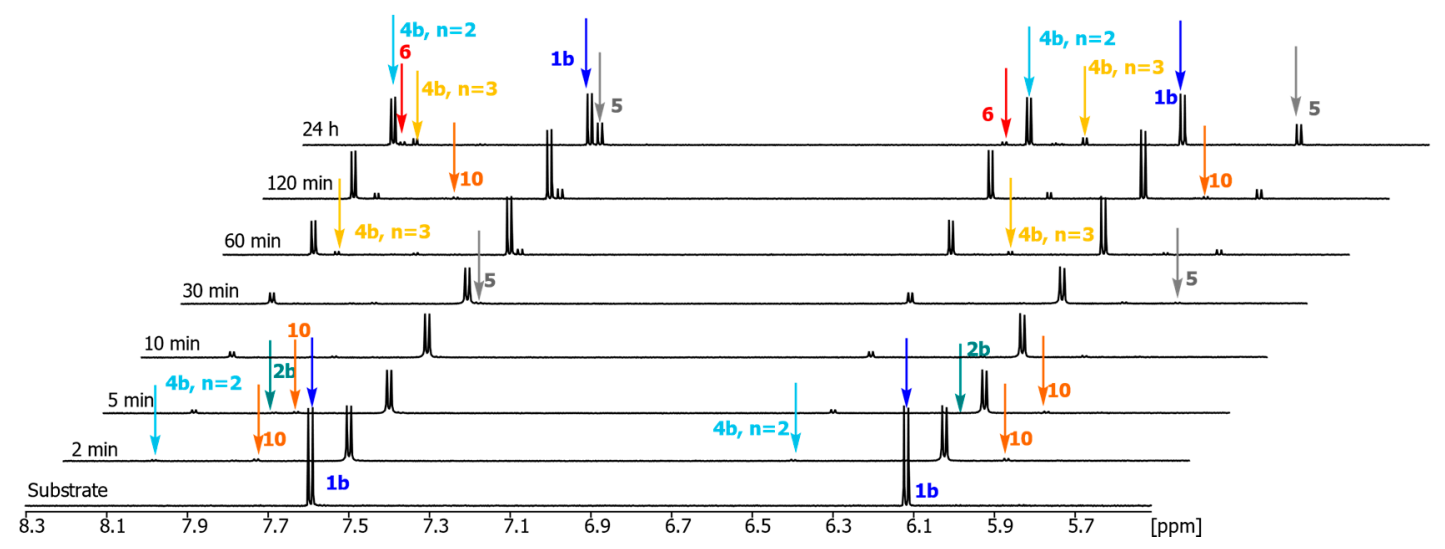

Figure 6. ${ }^{1} \mathrm{H}$ NMR spectra collected for the reaction of S2Ura (1b, $\left.10 \mathrm{mM}\right)$ with $\mathrm{H}_{2} \mathrm{O}_{2}(10 \mathrm{mM})$ in $67 \mathrm{mM}$ phosphate buffer at pH 7.4 and r.t. at the time points indicated on the left-hand side of each spectrum. 


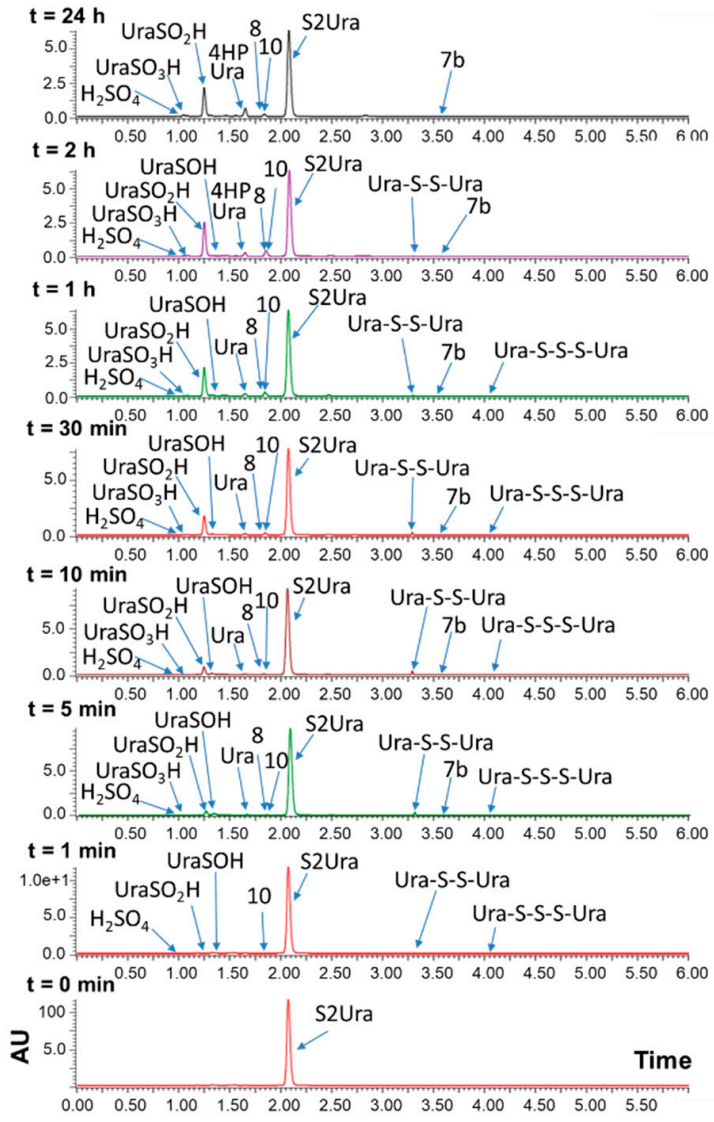

(a)

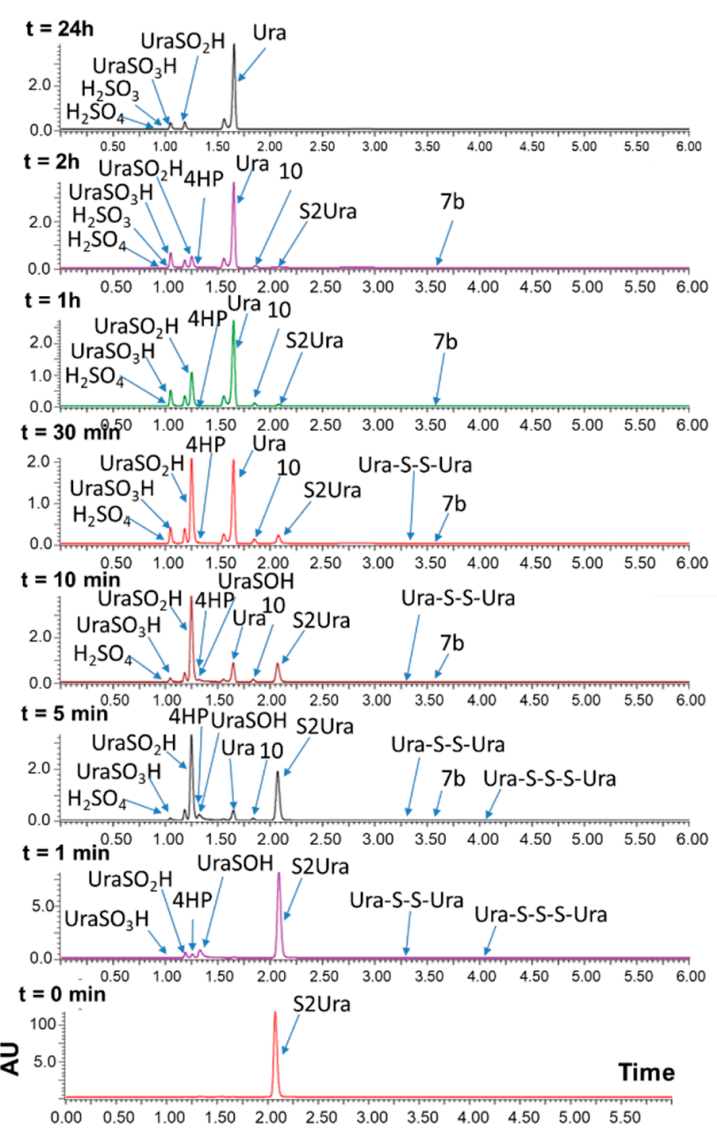

(b)

Figure 7. UPLC-PDA chromatographic analysis of the reaction mixtures of oxidation of S2Ura (1) $10 \mathrm{mM}$ ) with $\mathrm{H}_{2} \mathrm{O}_{2}(10 \mathrm{mM})\left(\right.$ a) or with $\mathrm{H}_{2} \mathrm{O}_{2}(100 \mathrm{mM})(\mathbf{b})$ in $67 \mathrm{mM}$ phosphate buffer at $\mathrm{pH} 7.4$, r.t. Mass spectra of all compounds identified here are shown in the Supplementary Materials. The $m / z$ data are given in Table 1. Inorganic sulfurous and sulfuric acids were identified by UPLC-ESI (-)-HRMS, and their retention times were determined based on extracted ion chromatograms (EICs) for the ions corresponding to their deprotonated molecules ( $\mathrm{m} / \mathrm{z} 80.9646$ and 96.9596, respectively).

\subsubsection{The Reaction of $\mathrm{S} 2 \mathrm{Ura}$ and $\mathrm{H}_{2} \mathrm{O}_{2}$ at a 1:10 Molar Ratio and $\mathrm{pH} 7.4$}

The reaction of $\mathbf{1 b}$ with a 10-fold molar excess of hydrogen peroxide was relatively fast, and the substrate disappeared after $2 \mathrm{~h}$ (Scheme 5, Figure S29 and Figure 7b). Initially, mainly sulfinic acid intermediate $4 \mathbf{b}\left(n=2 ;\right.$ Ura- $\left.\mathrm{SO}_{2} \mathrm{H}\right)(\mathrm{m} / z$ 158.9865) was observed, but after $30 \mathrm{~min}$, its content decreased, while the content of uracil increased. A minute amount of disulfide $\mathbf{2 b}(\mathrm{m} / \mathrm{z} 252.9853)$ was detected by ${ }^{1} \mathrm{H}$ NMR. The content of sulfonic acid $4 \mathbf{b}(n=3 ; m / z$ 174.9820) increased over the first hour of the reaction course. Traces of sulfenic acid $4 \mathbf{b}(n=1 ; m / z$ 142.9921), 4-pyrimidinone $(6, m / z$ 95.0239), and Bunte salt 10 (m/z 206.9539), as well as two-ring compound $7 \mathbf{b}(\mathrm{m} / \mathrm{z} 221.0135)$, were identified in UPLC-HRMS analysis. After $24 \mathrm{~h}$, only the resonance signals of uracil 5 were present in the NMR spectrum, but traces of sulfinic and sulfonic acids were still detected in the UPLC-MS chromatogram (Figure 7b). 


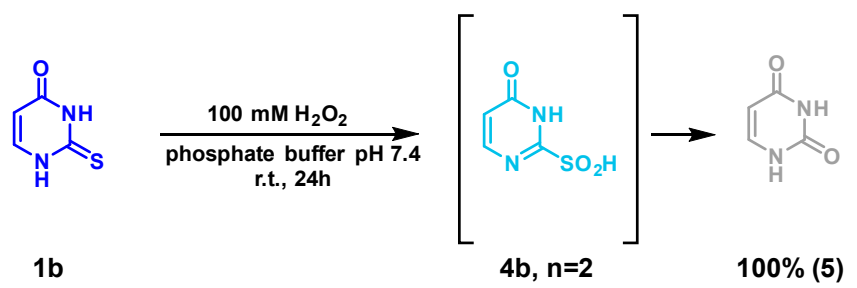

Scheme 5. Oxidation products of 2-thiouracil $(10 \mathrm{mM})$ carried out with $\mathrm{H}_{2} \mathrm{O}_{2}(100 \mathrm{mM})$ in phosphate buffer at $\mathrm{pH}$ 7.4.

\section{Discussion}

2-Selenouracil (1a, Se2Ura) and 2-thiouracil (1b, S2Ura) are relatively rare nucleobases present in transfer RNAs (http://modomics.genesilico.pl [20], http://mods.rna.albany.edu [21]). Within presumably acceptable simplification (no specific substituent at position C5), these compounds may be used as models in preliminary investigations of the processes occurring with tRNA under oxidative stress conditions. Both compounds are sufficiently soluble in aqueous solutions for ${ }^{1} \mathrm{H}$ NMR spectroscopy (in $\mathrm{D}_{2} \mathrm{O}$ ) and advanced high-resolution LC/MS analysis.

Generally, our investigations have shown that 2-selenouracil (1a) and 2-thiouracil (1b) have significantly different redox properties (Scheme 6, the red path is preferable for selenium components, and the blue path is preferable for sulfur components). Compound 1a is extremely prone to $\mathrm{H}_{2} \mathrm{O}_{2}$-assisted oxidation, plausibly resulting in the formation of selenenic acid $4 \mathbf{a}(n=1$, Ura-SeOH). This very reactive compound is not identified in the first few minutes of the reaction (it is detected later on in a relatively complex reaction mixture) since, probably, it reacts rapidly with $\mathbf{1 a}$, producing diselenide 2a. This path is in agreement with the results of the reaction carried out with 0.5 equivalents of $\mathrm{H}_{2} \mathrm{O}_{2}$, where $\mathbf{2} \mathbf{a}$ is almost exclusively formed (Figure 5 and Figure S24) from $\mathbf{1 a}$ and $\mathbf{4 a}(n=1)$. According to our assumption, this pathway of oxidation includes the two following steps: (i) Ura-SeH $\rightarrow$ Ura-SeOH and (ii) Ura-SeH + Ura-SeOH $\rightarrow$ Ura-Se-Se-Ura.

On the other hand, according to the literature data [22], diselenide R-Se-Se-R under alkaline conditions may hydrolyze to R-SeH and selenenic acid R-SeOH, and the latter, as an extremely unstable derivative, may disproportionate to produce the $\mathrm{R}-\mathrm{SeH}$ substrate and seleninic acid $\mathrm{R}-\mathrm{SeO}_{2} \mathrm{H}$ (see Scheme 7). This mechanism may explain the partial reconstitution of $\mathrm{Ura}-\mathrm{SeH}$ (1a) from diselenide $2 \mathbf{a}$ (without a reducing environment).

We also demonstrate that the route for reconstitution of $\mathbf{1 a}$ from $\mathbf{2 a}$ is limited due to the consumption/depletion of diselenide $2 \mathbf{a}$ by its rapid intramolecular rearrangement, leading to the selenium-containing intermediate 7a called "Jaffe's base" (Scheme 1) [23]. In aqueous environments, this compound easily loses the selenium atom to form stable compound $\mathbf{8}$. The relevant mechanism is similar to that proposed for the formation of "Jaffe's base" during the oxidation of ethylene thiourea (Scheme 8a) [24]. This reaction, obviously, does not take place on the level of tRNA, when Se2Ura is built in the nucleoside moiety. However, one cannot exclude the possibility that the Se2U-tRNA is metabolized (nucleolytically degraded [25]) to Se2Ura, which, in oxidative stress, might be transformed into two- and three-ring products described herein.

There are some reports suggesting that 2-selenouracil derivatives substituted at the $\mathrm{C} 6$ position with alkyl groups react with iodine to form corresponding R6Ura-SeI ${ }_{2}$ complexes (where $\mathrm{R}=$ methyl, ethyl, n-propyl, or iso-propyl), which may further react with the starting selenouracil R6Se2Ura to form the two-ring products R6Se2Ura-R6Ura, which are deprived of the selenium atom in ring b [26]. As shown by crystallographic analysis, these products have a covalent bond between $\mathrm{N}_{\mathrm{a}}$ of one R6Se2Ura (a) ring and the $\mathrm{C}_{\mathrm{b}}$ atom of the second R6Se2Ura molecule (b). Ultimately, these compounds spontaneously transform into four-ring derivatives in which the two-ring components are linked with a diselenide bridge. Alternatively, in aqueous solutions, these compounds undergo deselenation and cleavage of the $\mathrm{N}_{\mathrm{a}}-\mathrm{C} 2_{\mathrm{b}}$ bond, leading to the uracil molecule being substituted with an alkyl group at position 6 . 
In contrast to the cited two-ring compound R6Se2Ura( $\left(\mathrm{N}_{\mathrm{a}}\right)-\left(\mathrm{C}_{\mathrm{b}}\right) \mathrm{R} 6 \mathrm{Ura}$, the two-ring compound 8 reported here has a spanning bond between the $\mathrm{C} 2_{b}$ and $N 1_{a}$ atoms, as documented by 2D NMR studies (Figure 4a). If the amount of oxidant is stoichiometrically limiting (see data for a 1:0.5 molar ratio of reactants at $\mathrm{pH} 7.4$ ), or the reaction occurs under more basic conditions ( $\mathrm{pH} 8$ ), derivative 8 could be transformed to three-ring product 9 with a yield up to $26 \%$ of the total content. At first, we have supposed that compound $\mathbf{9}$ is a product of the condensation of $\mathbf{8}$ with $\mathbf{1 a}$, with the departure of hydrogen selenide as a second product (according to the mechanism proposed in Figure S30). If so, this reaction is expected to run between $\mathbf{8}$ and $\mathbf{1 a}$ without any additional reagent. However, as shown by the ${ }^{1} \mathrm{H}$ NMR analysis of 8 in the mixture with an excess of $\mathbf{1 a}$ (0.4:1 molar ratio), only signals of traces of compound 9 are noted after $24 \mathrm{~h}$. However, the prolonged incubation time of this mixture up to 7 days allowed to increase the content of 9 up to ca $14 \%$, while the content of 1 a clearly decreased to $32 \%$ (Fig. S30). Interestingly, when the same reaction was tested (8 and 1a, 0.4:1 molar ratio) but with the addition of 0.5 eq. of hydrogen peroxide over $1 \mathrm{a}$, the formation of 9 after $1 \mathrm{~h}$ was observed, to reach finally the yield of ca. 14\% after $24 \mathrm{~h}$ (see Figure S31). Thus, we conclude that compound 9 is mostly a product of the condensation of $\mathbf{8}$ and $\mathbf{2 a}$, as shown in Scheme $8 \mathbf{b}$, in which 2-selenouracil 1a and selenium are released, Thus, the reconstituted 2-selenouracil, present as a final product in the reaction, shown in Scheme 2, may originate from the diselenide reacting with compound 8.

In general, we can summarize that 2-selenouracil (1a) in the presence of a stoichiometrically limiting amount of the oxidant is preferably transformed to diselenide $\mathbf{2 a}$, which spontaneously rearranges to the two-ring product 8 , which, in turn, reacts with the remaining diselenide 2 a to yield 9 (red path, Scheme 6).

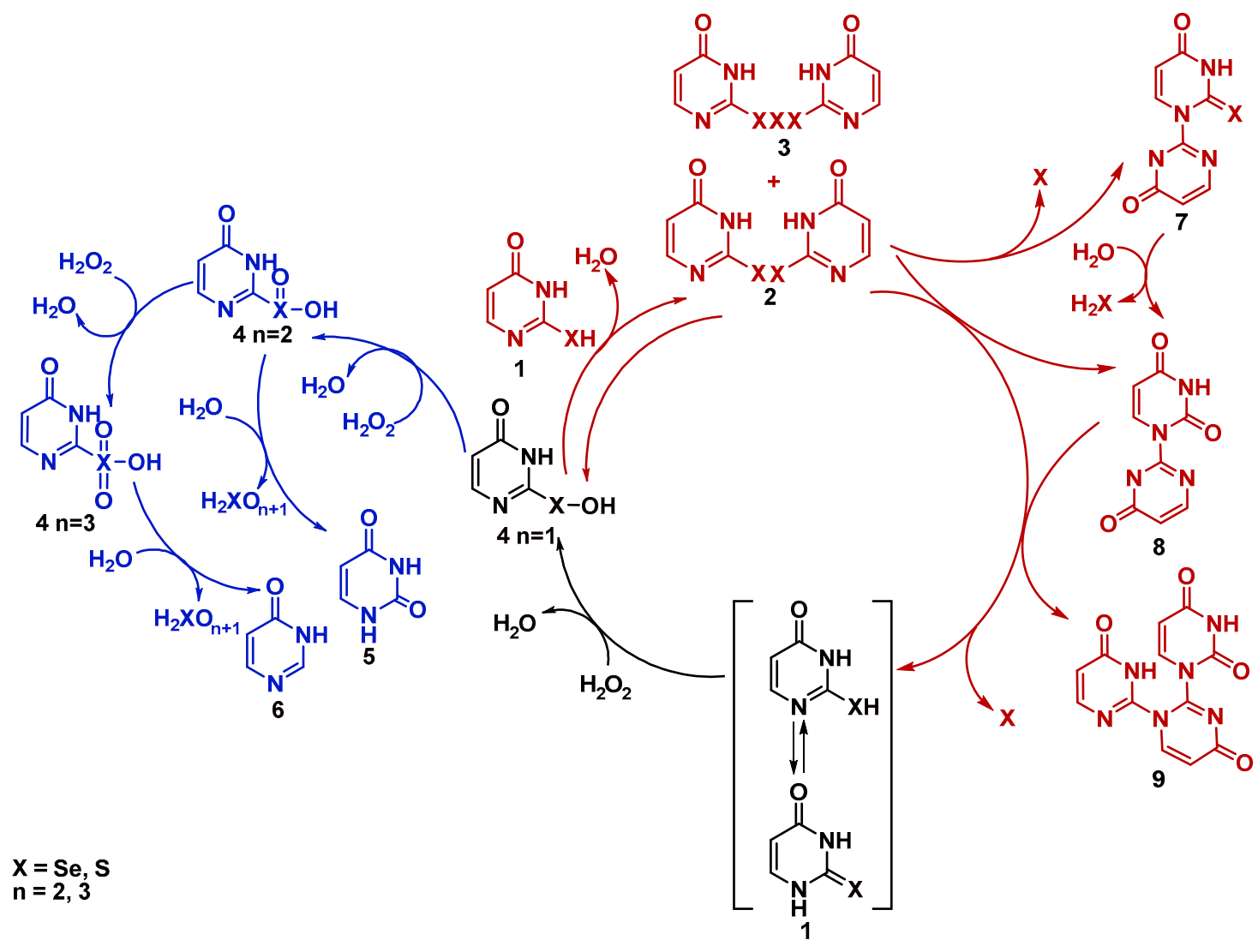

Scheme 6. Proposed transformation pathways for Se2Ura (1a) and S2Ura (1b) under oxidizing conditions. The red path is preferable for 2-selenouracil 1a, and the blue path is preferable for 2-thiouracil 1b. 


$$
\begin{aligned}
& 3 \mathrm{R}^{1}-\mathrm{Se}-\mathrm{Se}-\mathrm{R}^{2}+3 \mathrm{H}_{2} \mathrm{O} \longrightarrow 3 \mathrm{R}^{1}-\mathrm{SeOH}+3 \mathrm{R}^{2}-\mathrm{SeH} \\
& 2 \mathrm{R}-\mathrm{SeOH} \quad \longrightarrow \quad \mathbf{R}^{1}-\mathrm{SeO}_{2} \mathrm{H}+\mathbf{R}^{1}-\mathrm{SeH} \\
& \mathbf{R}^{1}-\mathrm{SeOH}+\mathbf{R}^{1}-\mathrm{SeH} \longrightarrow \mathrm{R}^{1}-\mathrm{Se}-\mathrm{Se}-\mathbf{R}^{1}+\mathrm{H}_{2} \mathrm{O} \\
& 3 \mathbf{R}-\mathrm{Se}-\mathrm{Se}-\mathbf{R}^{2}+2 \mathrm{H}_{2} \mathrm{O} \longrightarrow 3 \mathbf{R}^{2}-\mathrm{SeH}+\mathbf{R}^{1}-\mathrm{Se}-\mathrm{Se}-\mathbf{R}^{1}+\mathbf{R}^{1}-\mathrm{SeO}_{2} \mathrm{H}
\end{aligned}
$$

Scheme 7. A possible scheme of hydrolysis of diselenides under basic conditions [22].

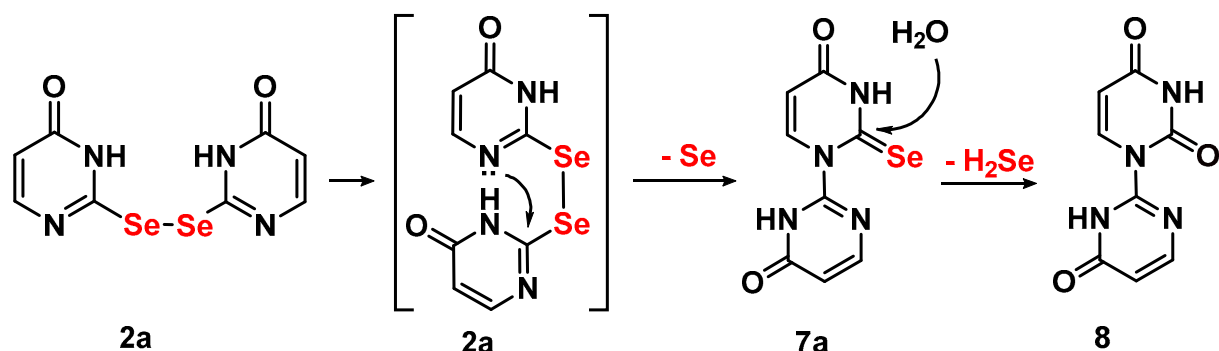

(a)<smiles></smiles>

2a<smiles></smiles>

8<smiles>O=c1ccnc(-n2ccc(=O)[nH]c2=O)[nH]1</smiles>

9<smiles>O=c1cc[nH]c(=S)[nH]1</smiles>

$1 \mathrm{a}$

(b)

Scheme 8. The proposed mechanism of formation of two-ring compounds $7 \mathbf{a}$ and 8 (a) and three-ring compound 9 (b).

This type of rearrangement has not been reported earlier for the oxidation experiments carried out with c5Se2Ura [18]. In this cited work, the oxidation of c5Se2Ura furnishes oxidized forms of c5Se2Ura and uracil. In our case, in contrast, the main component is the two-ring product 8 . This inconsistency may originate from the use of Se2Ura bearing a carboxyl substituent in position C5, which exerts an electron-withdrawing effect (both by induction and resonance). This effect is evidenced by the change in the $\mathrm{pKa}$ value from 7.18 for Se2Ura (1a) to 7.11 for c5Se2Ura. A similar effect has been observed for 2-thiouracils, where the pKa value changes from 7.75 for S2Ura (1b) to 7.68 for c5S2Ura [27].

The route leading to diselenide $\mathbf{2 a}$ and its rearrangement to $\mathbf{7 a}, \mathbf{8}$, and $\mathbf{9}$ is less favorable if the oxidant is present in high excess (see Figures S25 and S26). In these conditions, the prevalent formation of seleninic acid $4 \mathbf{a}\left(n=2, \mathrm{Ura}-\mathrm{SeO}_{2} \mathrm{H}\right)$ is noted, which, in aqueous solutions, undergoes water-assisted hydrolysis, resulting in the formation of uracil (5) (89\%) accompanied by elimination of selenium (IV) oxide, which reacts with water to form $\mathrm{H}_{2} \mathrm{SeO}_{3}$ (blue path, Scheme 6). Besides, it is worth mentioning that, according to published data, in the presence of excess hydrogen peroxide, the diselenides are further oxidized to selenoseleninate derivatives (-Se(O)-Se-), which are unstable under basic conditions [28-30]. These compounds are hydrolyzed to seleninic acid $\left(\mathrm{RSeO}_{2} \mathrm{H}\right)$ and selenol (RSeH), while, in acidic environments, selenenic acid (RSeOH) is formed [31]. Our efforts to confirm such transformation pathways have been unsuccessful, probably due to the low stability of the selenoseleninate derivative. 
It is noteworthy that, in the Hondal team's work [18], treatment of 5-carboxy-2-selenouracil (c5Se2Ura, $100 \mathrm{mM}$ ) with 1 molar equivalent of $\mathrm{H}_{2} \mathrm{O}_{2}$ after $18 \mathrm{~h}$ led to a product resonating at $\delta 1273 \mathrm{ppm}$ in ${ }^{77} \mathrm{Se} \mathrm{NMR}$, which was assigned as seleninic acid c5Ura-SeO ${ }_{2} \mathrm{H}$. In our reaction carried out in phosphate buffer at $\mathrm{pH} 7.4$, seleninic acid $\mathrm{Ura}_{-} \mathrm{SeO}_{2} \mathrm{H}(\mathbf{4 a}, n=2)$ is present only in the first several minutes, while inorganic seleninic acid $\mathrm{H}_{2} \mathrm{SeO}_{3}$ is present after $1 \mathrm{~h}$ (see Figure 2a). In addition, similar chemical shifts are known to be associated with $\mathrm{Na}_{2} \mathrm{SeO}_{3}\left(1263 \mathrm{ppm}\right.$ ) and $\mathrm{H}_{2} \mathrm{SeO}_{3}$ (1300 ppm) [32].

Unlike 2-selenouracil (1a), 2-thiouracil (1b) is less prone to oxidation with $\mathrm{H}_{2} \mathrm{O}_{2}$. The reaction is remarkably slower, and a 10-fold molar excess of oxidant leads to predominant conversion to uracil (5) (Scheme 5). With equal or stoichiometrically limiting amounts of $\mathrm{H}_{2} \mathrm{O}_{2}$, ca. $40 \%$ of $\mathbf{1 b}$ remains intact. The identified intermediates include sulfenic acid $4 \mathbf{b}(n=1, \mathrm{Ura}-\mathrm{SOH})$, sulfinic acid $4 \mathbf{b}(n=2$, Ura- $\left.\mathrm{SO}_{2} \mathrm{H}\right)$, and sulfonic acid $4 \mathbf{b}\left(n=3, \mathrm{Ura}-\mathrm{SO}_{3} \mathrm{H}\right)$ (Scheme 6, blue). Notably, among those three acid forms, sulfinic acid (Ura-SO ${ }_{2} \mathrm{H}$ ) is the most abundant, as shown by ${ }^{1} \mathrm{H}$ NMR analysis (having the highest signal integration and the longest time, the signals remained in the reaction mixture). Similar to sulfonic acid (Ura-SO $\mathrm{S}_{3} \mathrm{H}$ ), this compound can eliminate sulfur oxide upon nucleophilic substitution of a water molecule at the $\mathrm{C} 2$ position of the nucleobase ring. Although the small amount of 4-pyrimidinone (6) is identified, this process is marginal in comparison to the previously reported data for 2-thiouridines [13-17]. Traces of disulfide $\mathbf{1} \mathbf{b}$, trisulfide $\mathbf{1} \mathbf{c}$, or bicyclic compounds $\mathbf{7 b}$ and 8 (detected by UPLC-HRMS) indicate that while the responses of S2Ura and Se2Ura to hydrogen peroxide are common, their different redox properties are decisive for the preferred paths and the final content of oxidized products.

\section{Materials and Methods}

\subsection{Methods and Instrumentation}

\subsubsection{NMR Spectroscopy}

${ }^{1} \mathrm{H},{ }^{13} \mathrm{C}, \mathrm{COSY}$ (COrrelation SpectroscopY), HMQC (Heteronuclear Multiple Quantum Correlation) and HMBC NMR spectra were recorded on a Bruker Avance $700 \mathrm{MHz}$ spectrometer. The NMR spectra for ${ }^{1} \mathrm{H}$ and ${ }^{13} \mathrm{C}$ were recorded at $700 \mathrm{MHz}$ and $176 \mathrm{MHz}$, respectively. Chemical shifts $(\delta)$ are reported in ppm, and the signal multiplicities are described as s (singlet), $d$ (doublet), $t$ (triplet), q (quartet), $\mathrm{m}$ (multiplet). Coupling constants are reported in hertz $(\mathrm{Hz})$.

4.1.2. Ultra-Performance Liquid Chromatography Coupled with a High-Resolution Mass Spectrometry and Photodiode Array Detection (UPLC-PDA-ESI(-)-HRMS)

The identification of the reaction products was carried out using an ACQUITY UPLC I-Class chromatography system equipped with a photodiode array detector with a binary solvent manager (Waters Corp., Milford, MA, USA ) coupled with an SYNAPT G2-Si mass spectrometer equipped with an electrospray source and quadrupole-Time-of-Flight mass analyzer (Waters Corp., Milford, MA, USA). An Acquity HSS T3 $1.8 \mu \mathrm{m}$ column $(100 \times 2.1 \mathrm{~mm})$ (Waters Corp., Milford, MA) thermostated at $30{ }^{\circ} \mathrm{C}$ was used for the chromatographic separation of the analyte. A gradient program was employed with the mobile phase combining solvent $\mathrm{A}\left(10 \mathrm{mM} \mathrm{CH}_{3} \mathrm{COONH}_{4}\right)$ and solvent $\mathrm{B}\left(50 \% \mathrm{CH}_{3} \mathrm{CN}\right.$ in $\left.10 \mathrm{mM} \mathrm{CH}_{3} \mathrm{COONH}_{4}\right)$ as follows: $10 \% \mathrm{~B}(0-1.0 \mathrm{~min}), 10-95 \% \mathrm{~B}(1.0-3.5 \mathrm{~min}), 95-99 \% \mathrm{~B}(3.5-4.0 \mathrm{~min})$, $95-10 \% \mathrm{~B}(4.0-4.1 \mathrm{~min})$, and $10-10 \% \mathrm{~B}(4.1-6 \mathrm{~min})$. The flow rate was $0.2 \mathrm{~mL} / \mathrm{min}$, and the injection volume was $1 \mu \mathrm{L}$.

For mass spectrometric detection, the electrospray source was operated in a negative, high-resolution mode at a 50,000 FWHM resolving power of the TOF analyzer. To ensure accurate mass measurements, data were collected in centroid mode, and mass was corrected during acquisition using leucine encephalin solution as an external reference, Lock-Spray ${ }^{\mathrm{TM}}$, (Waters Corp., Milford, MA, USA), which generated reference ion at $m / z 554.2615$ ([M-H]) in negative ESI mode. The optimized source parameters were: capillary voltage $3 \mathrm{kV}$, cone voltage $20 \mathrm{~V}$, source temperature $90^{\circ} \mathrm{C}$, 
desolvation gas (nitrogen) flow rate $600 \mathrm{~L} / \mathrm{h}$ with the temperature $350{ }^{\circ} \mathrm{C}$, nebulizer gas pressure $6.5 \mathrm{bar}$. Mass spectrometer conditions were optimized by direct infusion of the standard solution. Mass spectra would be recorded over an $\mathrm{m} / \mathrm{z}$ range of 100 to 1200 . Collision-induced fragmentation experiments were performed using argon as the collision gas. The collision energy was ramped from 15 to $35 \mathrm{eV}$.

The PDA spectra were measured over the wavelength range of $210-400 \mathrm{~nm}$ in steps of $1.2 \mathrm{~nm}$.

The results of the measurements were processed using the MassLynx 4.1 software (Waters) incorporated with the instrument.

\subsubsection{Ultraviolet Spectroscopy Measurements (UV)}

UV spectra were recorded on a Specord ${ }^{\circledR} 50$ plus spectrophotometer. Samples were prepared by dilution of $4 \mu \mathrm{L}$ of stock compounds solution (stock solution-ca $1 \mathrm{mg}$ of compound in $1 \mathrm{~mL}$ water) in $996 \mu \mathrm{L}$ of buffer solutions $(1 \mathrm{mM} \mathrm{HCl}$ at $\mathrm{pH} 3.0,67 \mathrm{mM}$ phosphate buffer at $\mathrm{pH}$ 5.0, 6.0, 6.5, 7.0, 7.5, 8.0, $0.1 \mathrm{mM} \mathrm{NaOH}$ at $\mathrm{pH} 10)$.

\subsection{Experimental Section}

\subsubsection{Materials}

All materials, including 2-thiouracil, were purchased from Sigma Aldrich (St. Louis, MO, USA) or TCI Europe $n$. V., (Zwijndrecht, Belgium).

\subsubsection{Synthesis of 2-Selenouracil}

The synthesis of 2-selenouracil was done according to the published procedure [33], with slight improvement, and is described in Supplementary Materials.

\subsection{3. ${ }^{1} \mathrm{H}-\mathrm{NMR}$ Analysis of Oxidation Assays of $\mathbf{1 a}$ and $\mathbf{1 b}$}

A $10 \mathrm{mM}$ solution of either $\mathbf{1 a}$ or $\mathbf{1 b}$ was prepared in $67 \mathrm{mM}$ phosphate buffer $(\mathrm{pH} 7.4, \mathrm{pH} 8.0$, $\mathrm{pH}$ 5.0) or deionized water (using $\mathrm{D}_{2} \mathrm{O}$ ). The first ${ }^{1} \mathrm{H}$ NMR spectrum was acquired to establish the initial point. Compounds $\mathbf{1 a}$ or $\mathbf{1 b}$ were treated with 1 or 10 equivalents of $\mathrm{H}_{2} \mathrm{O}_{2}$. The reactions were monitored by ${ }^{1} \mathrm{H}$ NMR, and the spectra were acquired after 1 or $2 \mathrm{~min}, 5 \mathrm{~min}, 20 \mathrm{~min}, 30 \mathrm{~min}, 60 \mathrm{~min}$, $120 \mathrm{~min}$, and $24 \mathrm{~h}$.

\subsubsection{UPLC-PDA-ESI (-)-HRMS Analysis of the Oxidation Assays of $\mathbf{1 a}$ and $\mathbf{1 b}$}

The $10 \mathrm{mM}$ solutions of either $\mathbf{1 a}$ or $\mathbf{1 b}$ were prepared in $67 \mathrm{mM}$ phosphate buffer ( $\mathrm{pH} 7.4)$ and then were treated with 1 or 10 equivalents of $\mathrm{H}_{2} \mathrm{O}_{2}$. The reactions were monitored by UPLC-PDA-ESI (-)-HRMS, and the spectra were acquired after 1, 5, 10, 30, 60, and $120 \mathrm{~min}$ and $24 \mathrm{~h}$.

\section{Conclusions}

By a series of oxidation experiments carried out on 2-seleno- and 2-thiouracil (1a and 1b), we demonstrated that Se2Ura is more prone to oxidation than the sulfur analog. In the first step of oxidation of 1a with $\mathrm{H}_{2} \mathrm{O}_{2}$ (1:0.5 molar ratio), diselenide 2a is exclusively formed, which is, as we suggest, the product of the condensation of selenenic acid (Ura-SeOH) and Ura-SeH. Diselenide 2a spontaneously undergoes Jaffe's rearrangement to the two-ring product 7a, which, upon deselenation, gives $\mathbf{8}$, the major component of the reaction mixture. If diselenide $\mathbf{2} \mathbf{a}$ is still present in the reaction mixture, it reacts with 8 to give the three-ring product 9. These new paths make 2-seleno-uracil unsuitable as a model for the analysis of oxidative stress in transfer RNAs. On the other hand, only excess hydrogen peroxide causes oxidation of S2Ura. This process proceeds via sulfenic (Ura-SOH), sulfinic $\left(\mathrm{Ura}-\mathrm{SO}_{2} \mathrm{H}\right)$, and sulfonic $\left(\mathrm{Ura}-\mathrm{SO}_{3} \mathrm{H}\right)$ intermediates, and finally, after the elimination of sulfur oxides $\left(\mathrm{SO}_{\mathrm{n}}, n=2\right.$ or 3$)$, uracil is restored. Thus, we conclude that 2 -selenouracil is oxidized more easily than 2-thiouracil, and the dominating oxidation path depends on (i) the concentration of reactants, 
(ii) excess oxidant, and (iii) the $\mathrm{pH}$ of the reaction mixture. Moreover, since the two- and three-ring products may be potential metabolites of degradation/oxidation of selenium-modified transfer RNAs, it is of interest to elaborate their influence on cell biology.

Supplementary Materials: Supplementary Materials can be found at http://www.mdpi.com/1422-0067/21/17/ 5956/s1. Chemistry: Synthesis of 2-selenouracil (Se2Ura, 1a); Figure S1. ${ }^{1} \mathrm{H}$ NMR spectrum of 1a; Figure S2. ESI(-)-HRMS analysis and UV spectrum of 1a; Figure S3. ESI(-)-HRMS analysis and UV spectrum of 2a; Figure S4. ESI(-)-HRMS analysis and UV spectrum of 3a; Figure S5. ESI(-)-HRMS analysis of $4 \mathbf{a},(n=1)$; Figure S6. ESI(-)-HRMS analysis and UV spectrum of $4 \mathbf{a},(n=2)$; Figure S7. ESI(-)-HRMS analysis and UV spectrum of 6; Figure S8. ESI(-)-HRMS analysis and UV spectrum of 7a; Figure S9. NMR analysis of 8: (A) ${ }^{1} \mathrm{H} N \mathrm{NMR}$, (B) ${ }^{13} \mathrm{C}$ NMR, (C) COSY, (D) HMQC; Figure S10. ESI(-)-HRMS analysis and UV spectrum of 8; Figure S11. NMR analysis of 9: (A) ${ }^{1} \mathrm{H}$ NMR, (B) 13C NMR, (C) COSY, (D) HMQC; Figure S12. ESI(-)-HRMS analysis and UV spectrum of 9; Figure S13. The $\mathrm{pH}$-dependent UV spectra of 9 in the $\mathrm{pH}$ range from 3 to 10; Figure S14. ESI(-)-HRMS analysis and UV spectrum of $\mathbf{2 b}$; Figure S15. ESI(-)-HRMS analysis of $\mathbf{3 b}$; Figure S16. ESI(-)-HRMS analysis of $\mathbf{4 b},(n=1)$; Figure S17. ESI(-)-HRMS analysis of $\mathbf{4} \mathbf{b},(n=2)$; Figure S18. ESI(-)-HRMS analysis and UV spectrum of $\mathbf{4} \mathbf{b},(n=3)$; Figure S19. ESI(-)-HRMS analysis of $\mathbf{7 b}$; Figure S20. ESI(-)-HRMS analysis and UV spectrum of 10; Figure S21. ${ }^{1} \mathrm{H}$ NMR analysis of the reaction mixtures for oxidation of Se2Ura $(\mathbf{1 a}, 10 \mathrm{mM})$ with $\mathrm{H}_{2} \mathrm{O}_{2}(10 \mathrm{mM})$ in $67 \mathrm{mM}$ phosphate buffer $\mathrm{pH}$ 8.0, at room temperature; FigureS22. ${ }^{1} \mathrm{H}$ NMR analysis of the reaction mixtures for oxidation of Se2Ura $(\mathbf{1 a}, 10 \mathrm{mM})$ with $\mathrm{H}_{2} \mathrm{O}_{2}(10 \mathrm{mM})$ in $67 \mathrm{mM}$ phosphate buffer $\mathrm{pH}$ 5.0, at room temperature; Figure S23. ${ }^{1} \mathrm{H}$ NMR analysis of the reaction mixtures for oxidation of Se2Ura $(\mathbf{1 a}, 10 \mathrm{mM})$ with $\mathrm{H}_{2} \mathrm{O}_{2}(10 \mathrm{mM})$ in water, at room temperature; Figure S24. ${ }^{1} \mathrm{H}$ NMR analysis of the reaction mixtures for oxidation of Se2Ura (1a, $10 \mathrm{mM}$ ) with $\mathrm{H}_{2} \mathrm{O}_{2}(5 \mathrm{mM})$ in $67 \mathrm{mM}$ phosphate buffer $\mathrm{pH}$ 7.4, at room temperature; Figure S25. ${ }^{1} \mathrm{H}$ NMR analysis of the reaction mixtures for oxidation of Se2Ura $(\mathbf{1 a}, 10 \mathrm{mM})$ with $\mathrm{H}_{2} \mathrm{O}_{2}(100 \mathrm{mM})$ in $67 \mathrm{mM}$ phosphate buffer $\mathrm{pH}$ 7.4, at room temperature; Figure S26. UPLC-PDA chromatographic analysis of the reaction mixtures for oxidation of Se2Ura $(\mathbf{1 a}, 10 \mathrm{mM})$ with $\mathrm{H}_{2} \mathrm{O}_{2}(100 \mathrm{mM})$ in $67 \mathrm{mM}$ phosphate buffer $\mathrm{pH}$ 7.4, at room temperature; Figure S27. Product ion mass spectrum of 10; Time course of the oxidation of S2Ura (1b) by hydrogen peroxide monitored by ${ }^{1} \mathrm{H}$ NMR spectroscopy and UPLC-PDA-ESI(-)-HRMS; Figure S28. The time course of the formation of products for the oxidation reaction of S2Ura $(\mathbf{1 b}, 10 \mathrm{mM})$ with $\mathrm{H}_{2} \mathrm{O}_{2}(10 \mathrm{mM})$ in $67 \mathrm{mM}$ phosphate buffer $\mathrm{pH}$ 7.4, r.t.; Figure S29. ${ }^{1} \mathrm{H}$ NMR analysis of the reaction mixtures for oxidation of S2Ura $(\mathbf{1 b}, 10 \mathrm{mM})$ with $\mathrm{H}_{2} \mathrm{O}_{2}$ $(100 \mathrm{mM})$ in $67 \mathrm{mM}$ phosphate buffer $\mathrm{pH}$ 7.4, at room temperature (r.t.).; Fig. S30. ${ }^{1} \mathrm{H}$ NMR analysis ( $\mathrm{H} 5$ and $\left.\mathrm{H} 6\right)$ of the reaction of $8(4 \mathrm{mM})$ with $1 \mathrm{a}(10 \mathrm{mM})$ at the $0.4: 1$ molar ratio, at $67 \mathrm{mM}$ phosphate buffer $\mathrm{pH} 8$, r.t. Traces of compound 9 are seen after 17 and $24 \mathrm{~h}$ (signals of $\mathrm{H} 5$ and $\mathrm{H} 6$ protons are indicated by arrows). After 7 days of incubation the amount of 9 increased to ca. $14 \%$, while the amount of 1 a dropped down to ca. $32 \%$, while 8 was $52 \%$ and 5 was $2 \%$; Fig. S31. ${ }^{1} \mathrm{H}$ NMR analysis ( $\mathrm{H} 5$ and $\left.\mathrm{H} 6\right)$ of the reaction of $8(4 \mathrm{mM})$ and $1 \mathrm{a}(10 \mathrm{mM})$ at the $0.4: 1$ molar ratio, after addition of 0.5 eq. of $\mathrm{H}_{2} \mathrm{O}_{2}(5 \mathrm{mM})$, at $67 \mathrm{mM}$ phosphate buffer $\mathrm{pH} 8$, r.t. Signals of compound 9 are seen after $1 \mathrm{~h}$ (see signals of $\mathrm{H} 5$ and $\mathrm{H} 6$ protons indicated by arrows).

Author Contributions: Conceptualization, B.N. and E.S.; methodology, K.K., K.S., E.W., and B.P.-S.; investigation, B.N., E.S., K.K., K.S., E.W., and B.P.-S.; writing original draft preparation, K.K., K.S., E.W., and B.P.-S.; writingreview and editing, B.N., E.S., and K.K.; supervision, B.N. and E.S.; funding acquisition, B.N. and E.S. All authors have read and agreed to the published version of the manuscript.

Funding: This research was funded by The National Science Center in Poland (project UMO-2018/29/B/ST5/02509 to B.N.) and by statutory funds of the Lodz University of Technology and the Centre of Molecular and Macromolecular Studies, Polish Academy of Sciences. Funding for open access charge: The National Science Center in Poland.

Acknowledgments: Thanks are directed to Piotr Guga for critical reading of the manuscript.

Conflicts of Interest: The authors declare no conflict of interest.

\section{References}

1. Gilbert, H.F. Molecular and cellular aspects of thiol-disulfide exchange. In Advances in Enzymology and Related Areas of Molecular Biology; Meister, A., Ed.; John Wiley \& Sons: Hoboken, NJ, USA, 1990; Volume 63, pp. 69-172. [CrossRef]

2. Gilbert, H.F. Thiol/disulfide exchange equilibria and disulfide bond stability. Methods Enzymol. 1995, 251, 8-28. [CrossRef] [PubMed]

3. Gilbert, H.F. Thiol/disulfide exchange and redox potentials of proteins. In Bioelectrochemistry of Biomacromolecules: Principles and Practice; Lenaz, G., Milazzo, G., Eds.; Birkhäuser Verlag: Basel, Switzerland, 1997; pp. 256-324. [CrossRef]

4. Hondal, R.J.; Marino, S.M.; Gladyshev, V.N. Selenocysteine in thiol/disulfide-like exchange reactions. Antioxid. Redox Signal. 2013, 18, 1675-1689. [CrossRef] [PubMed] 
5. Yoshida, S.; Kumakura, F.; Komatsu, I.; Arai, K.; Onuma, Y.; Hojo, H.; Singh, B.G.; Priyadarsini, K.I.; Iwaoka, M. Antioxidative glutathione peroxidase activity of selenoglutathione. Angew. Chem. 2011, 50, 2125-2128. [CrossRef] [PubMed]

6. Kryukov, G.V.; Castellano, S.; Novoselov, S.V.; Lobanov, A.V.; Zehtab, O.; Guigó, R.; Gladyshev, V.N. Characterization of mammalian selenoproteomes. Science 2003, 300, 1439-1443. [CrossRef]

7. Ramming, T.; Hansen, H.G.; Nagata, K.; Ellgaard, L.; Appenzeller-Herzog, C. Gpx8 peroxidase prevents leakage of $\mathrm{H}_{2} \mathrm{O}_{2}$ from the endoplasmic reticulum. Free Radic. Biol. Med. 2014, 70, 106-116. [CrossRef]

8. Jacob, C.; Giles, G.; Giles, N.M.; Sies, H. Sulfur and selenium: The role of oxidation state in protein structure and function. Angew. Chem. 2003, 42, 4742-4758. [CrossRef]

9. Wessjohann, L.A.; Schneider, A.; Abbas, M.; Brand, W. Selenium in chemistry and biochemistry in comparison to sulfur. Biol. Chem. 2007, 388, 997-1006. [CrossRef]

10. Reich, H.J.; Hondal, R.J. Why Nature chose selenium. ACS Chem. Biol. 2016, 11, 821-841. [CrossRef]

11. Hondal, R.J.; Ruggles, E.L. Differing views of the role of selenium in thioredoxin reductase. Amino Acids 2011, 41, 73-89. [CrossRef]

12. Maroney, M.; Hondal, R.J. Selenium versus sulfur: Reversibility of chemical reactions and resistance to permanent oxidation in proteins and nucleic acids. Free Radic. Biol. Med. 2018, 127, 228-237. [CrossRef]

13. Sochacka, E.; Kraszewska, K.; Sochacki, M.; Sobczak, M.; Janicka, M.; Nawrot, B. The 2-thiouridine unit in the RNA strand is desulfured predominantly to 4-pyrimidinone nucleoside under in vitro oxidative stress conditions. Chem. Commun. 2011, 47, 4914-4916. [CrossRef] [PubMed]

14. Sochacka, E.; Szczepanowski, R.H.; Cypryk, M.; Sobczak, M.; Janicka, M.; Kraszewska, K.; Bartos, P.; Chwialkowska, A.; Nawrot, B. 2-Thiouracil deprived of thiocarbonyl function preferentially base pairs with guanine rather than adenine in RNA and DNA duplexes. Nucleic Acids Res. 2015, 11, 2499-2512. [CrossRef] [PubMed]

15. Sochacka, E.; Bartos, P.; Kraszewska, K.; Nawrot, B. Desulfuration of 2-thiouridine with hydrogen peroxide in the physiological $\mathrm{pH}$ range 6.6-7.6 is $\mathrm{pH}$-dependent and results in two distinct products. Bioorg. Med. Chem. Lett. 2013, 23, 5803-5805. [CrossRef] [PubMed]

16. Bartos, P.; Ebenryter-Olbinska, K.; Sochacka, E.; Nawrot, B. The influence of the C5 substituent on the 2-thiouridine desulfuration pathway and the conformational analysis of the resulting 4-pyrimidinone products. Bioorg. Med. Chem. 2015, 23, 5587-5594. [CrossRef] [PubMed]

17. Sierant, M.; Kulik, K.; Sochacka, E.; Szewczyk, R.; Sobczak, M.; Nawrot, B. Cytochrome C catalyzes the hydrogen peroxide-assisted oxidative desulfuration of 2-thiouridines in transfer RNAs. ChemBiochem 2018, 4, 687-695. [CrossRef] [PubMed]

18. Payne, N.C.; Geissler, A.; Button, A.; Sasuclark, A.R.; Schroll, A.L.; Ruggles, E.L.; Gladyshev, V.N.; Hondal, R.J. Comparison of the redox chemistry of sulfur- and selenium-containing analogs of uracil. Free Radic. Biol. Med. 2017, 104, 249-261. [CrossRef]

19. Leszczynska, G.; Cypryk, M.; Gostynski, B.; Sadowska, K.; Herman, P.; Bujacz, G.; Lodyga-Chruscinska, E.; Sochacka, E.; Nawrot, B. C5-Substituted 2-selenouridines ensure efficient base pairing with guanosine; consequences for reading the NNG-3' synonymous mRNA codons. Int. J. Mol. Sci. 2020, 21, 2882. [CrossRef]

20. Boccaletto, P.; Machnicka, M.A.; Purta, E.; Piątkowski, P.; Bagiński, B.; Wirecki, T.K.; de Crécy-Lagard, V.; Ross, R.; Limbach, P.A.; Kotter, A.; et al. MODOMICS: A database of RNA modification pathways. 2017 update. Nucl. Acids Res. 2018, 46, D303-D307. [CrossRef]

21. Cantara, W.A.; Crain, P.F.; Rozenski, J.; McCloskey, J.A.; Harris, K.A.; Zhang, X.; Vendeix, F.A.P.; Fabris DAgris, P.F. The RNA modification database, RNAMDB: 2011 update. Nucl. Acids Res. 2011, 39, D195-D201. [CrossRef]

22. Rheinboldt, H.; Giesbreoht, E. Unsymmetrische diselenide. Chem. Ber. 1952, 85, 357-368. [CrossRef]

23. Johnson, T.B.; Edens, C.O. Complex formations between iodine and $\mu$-mercapto-dihydroglyoxalines. J. Am. Chem. Soc. 1942, 64, 2706-2708. [CrossRef]

24. Marshall, W.; Singh, J. Oxidative inactivation of ethylenethiourea by hypochlorite in alkaline medium. J. Agric. Food Chem. 1977, 25, 1316-1320. [CrossRef] [PubMed]

25. Jackowiak, P.; Nowacka, M.; Strozycki, P.M.; Figlerowicz, M. RNA degradome-its biogenesis and functions. Nucl. Acids Res. 2011, 39, 7361-7370. [CrossRef] [PubMed] 
26. Antoniadis, C.D.; Hadjikakou, S.K.; Hadjiliadis, N.; Papakyriakou, A.; Baril, M.; Butler, I.S. Synthesis and structures of Se analogues of the antithyroid drug 6-n-propyl-2-thiouracil and its alkyl derivatives: Formation of dimeric Se-Se compounds and deselenation reactions of charge-transfer adducts of diiodine. Chem. Eur. J. 2006, 12, 6888-6897. [CrossRef] [PubMed]

27. Palumbo, A.; d'Ischia, M.; Cioffi, F.A. 2-Thiouracil is a selective inhibitor of neuronal nitric oxide synthase antagonising tetrahydrobiopterin-dependent enzyme activation and dimerization. FEBS Lett. 2000, 485, 109-112. [CrossRef]

28. Reich, H.J.; Hoeger, C.A.; Willis, J.W.W. Organoselenium chemistry. Characterization of reactive intermediates in the selenoxide syn elimination: Selenenic acids and selenolseleninate esters. J. Am. Chem. Soc. 1982, 104, 2936-2937. [CrossRef]

29. Reich, H.J.; Hoeger, C.A.; Willis, J.W.W. Organoselenium chemistry: A study of intermediates in the fragmentation of aliphatic ketoselenoxides. Characterization of selenoxides, selenenamides and selenolseleninates by ${ }^{1} \mathrm{H}-,{ }^{13} \mathrm{C}$-and ${ }^{77} \mathrm{Se}-\mathrm{NMR}$. Tetrahedron 1985, 41, 4771-4779. [CrossRef]

30. Ayrey, G.; Barnard, D.; Woodbridge, D.T. The oxidation of organoselenium compounds by ozone. J. Chem. Soc. 1962, 2089-2099. [CrossRef]

31. Ishii, A.; Takahashi, T.; Nakayama, J. Hydrolysis of an isolable selenoseleninate under acidic and alkaline conditions. Heteroatom Chem. 2001, 12, 198-203. [CrossRef]

32. Duddeck, H. 77Se NMR spectroscopy and its applications in chemistry. Annu. Reports NMR Spectrosc. 2004, 52, 105-166. [CrossRef]

33. Mautner, H.G. The synthesis and properties of some selenopurines and selenopyrimidines. J. Am. Chem. Soc. 1956, 78, 5292-5294. [CrossRef]

(C) 2020 by the authors. Licensee MDPI, Basel, Switzerland. This article is an open access article distributed under the terms and conditions of the Creative Commons Attribution (CC BY) license (http://creativecommons.org/licenses/by/4.0/). 